\title{
The internal geometry and lithofacies pattern of the Upper Cretaceous-Danian sequence in the Polish Lowlands
}

\author{
Krzysztof LESZCZYŃSKI
}

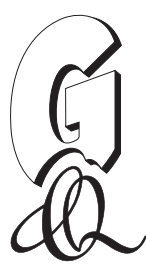

\begin{abstract}
Leszczyński K. (2012) - The internal geometry and lithofacies pattern of the Upper Cretaceous-Danian sequence in the Polish Lowlands. Geol. Quart., 56 (2): 363-386, doi: 10.7306/gq.1028

The paper presents a set of maps illustrating the internal geometry of the Upper Cretaceous-Danian sedimentary sequence in the Polish Lowlands. Qualitative lithofacies are used for reconstructions with the dominant lithofacies component and accessory components indicated. The following maps are produced: (1) base Upper Cretaceous structural map; (2) Upper Cretaceous (including Danian) thickness map; (3) thickness map of succession K3 (Cenomanian-lower Turonian, excluding the upper Albian cycle K3-I, which is the lowermost cycle of succession K3, but formally belongs to the Lower Cretaceous); (4) succession K4 (upper Turonian-Danian) thickness map. The maps of successions K3 and K4 illustrate the post-inversion geometry of the basin for the pre-inversion (Cenomanian-lower Turonian) and syn-inversion (upper Turonian-Danian) successions. Thickness analysis shows an increasing difference in subsidence rate during the Late Cretaceous between the areas extending on the two sides of the present-day Mid-Polish Swell. Much higher subsidence rates during deposition of succession $\mathrm{K} 4$ occurred in the area extending to the $\mathrm{SW}$ of the swell. The maximum subsidence zone migrated with time from the Pomeranian and Kujavian segments towards the Kujavian and Lublin segments. The lithofacies pattern is presented in seven maps constructed for individual eustatically and tectonically controlled cycles: K3-II-K3-III (early Cenomanian-early late Cenomanian), K3-IV (latest Cenomanian-early Turonian), K4-I (late Turonian-Coniacian), K4-II (Santonian-earliest Campanian), K4-III (late early Campanian-earliest Maastrichtian), K4-IV-K4-V (late early Maastrichtian-late Maastrichtian) and Pc-I (Danian-?earliest Selandian).
\end{abstract}

Krzysztof Leszczyński, Polish Geological Institute - National Research Institute, Rakowiecka 4, PL 00-975 Warszawa, Poland; e-mail: krzysztof.leszczynski@pgi.gov.pl (received: February 12, 2012, accepted: April 5, 2012; first published online: June 13, 2012).

Key words: Upper Cretaceous-Danian sequence, Polish Lowlands, structural and thickness maps, lithofacies pattern.

\section{INTRODUCTION}

The internal geometry of the Upper Cretaceous-Danian sequence in the Polish Lowlands, interpreted based on data from approximately 1100 boreholes (Fig. 1A), is illustrated by a set of maps (base Upper Cretaceous map, thickness maps and lithofacies maps). The study area covers the Late Cretaceous basin of the Polish Lowlands, which freely communicated with the other European basins and was dominated by carbonate sedimentation (Fig. 1B). Sedimentary cyclicity within the basin was controlled by eustatic and tectonic factors (Leszczyński, 1997). The relationship between the cyclicity and the most commonly used curves of relative sea level changes is illustrated in Figure 2.

The structural and thickness maps are compiled with respect to the base of the Cenomanian, which is the standard lower boundary of the Upper Cretaceous series (Birkelund et al., 1984; Rawson et al., 1995; Wagner, 2008; Fig. 3). It marks the onset of rapid expansion of the Late Cretaceous Sea in the Polish Basin and the beginning of widespread carbonate/chalk deposition in the European basins (Walaszczyk, 1987; Jaskowiak-Schoeneichowa and Krassowska, 1988b; Voigt et al., 2008; Vejbaek et al., 2010). Sedimentation of the Late Cretaceous megacycle was primarily related to the relative sea level rise initiated during the middle-late Albian and manifested by siliciclastic deposition on a shallow shelf. The sea level rise accelerated during Albian-Cenomanian times leading to the development of deeper-marine siliciclastic-carbonate facies followed by carbonate deposition over large areas. The carbonate-siliceous depositional system developed on a larger scale during the Turonian and dominated in the Polish Lowlands (especially in the basin centre) until the Maastrichtian and Danian (Jaskowiak-Schoeneichowa and Krassowska, 1988b; Krassowska, 1997; Leszczyński, 1997, 2010).

Beginning with the Turonian, chalk was deposited in relatively shallow-marine zones below the storm wave base, far 

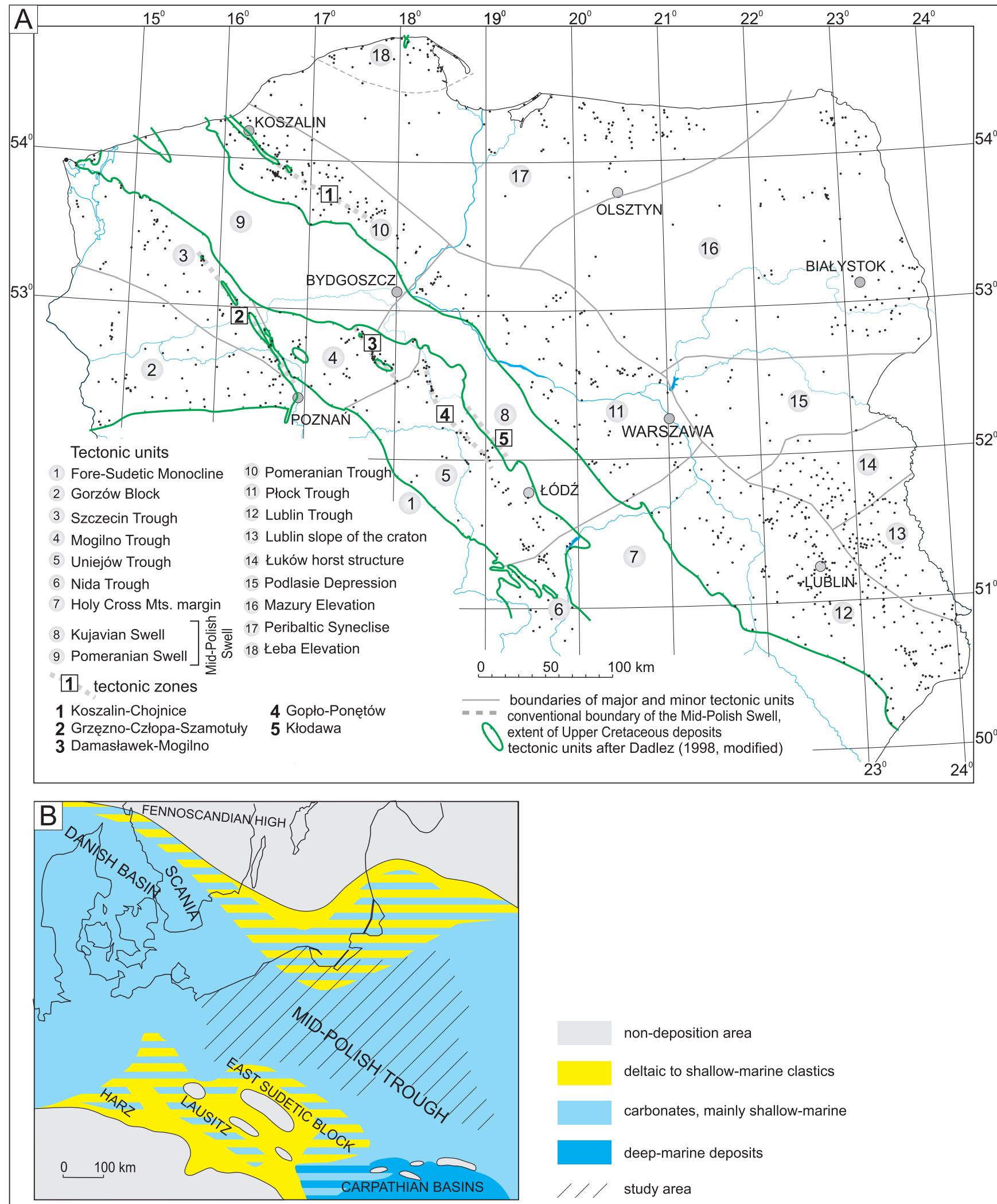

non-deposition area

deltaic to shallow-marine clastics

carbonates, mainly shallow-marine

deep-marine deposits

study area

Fig. 1A - location of boreholes, and main tectonic units;

B - palaeogeography in Cenomanian to Danian times (modified after Ziegler, 1982) 


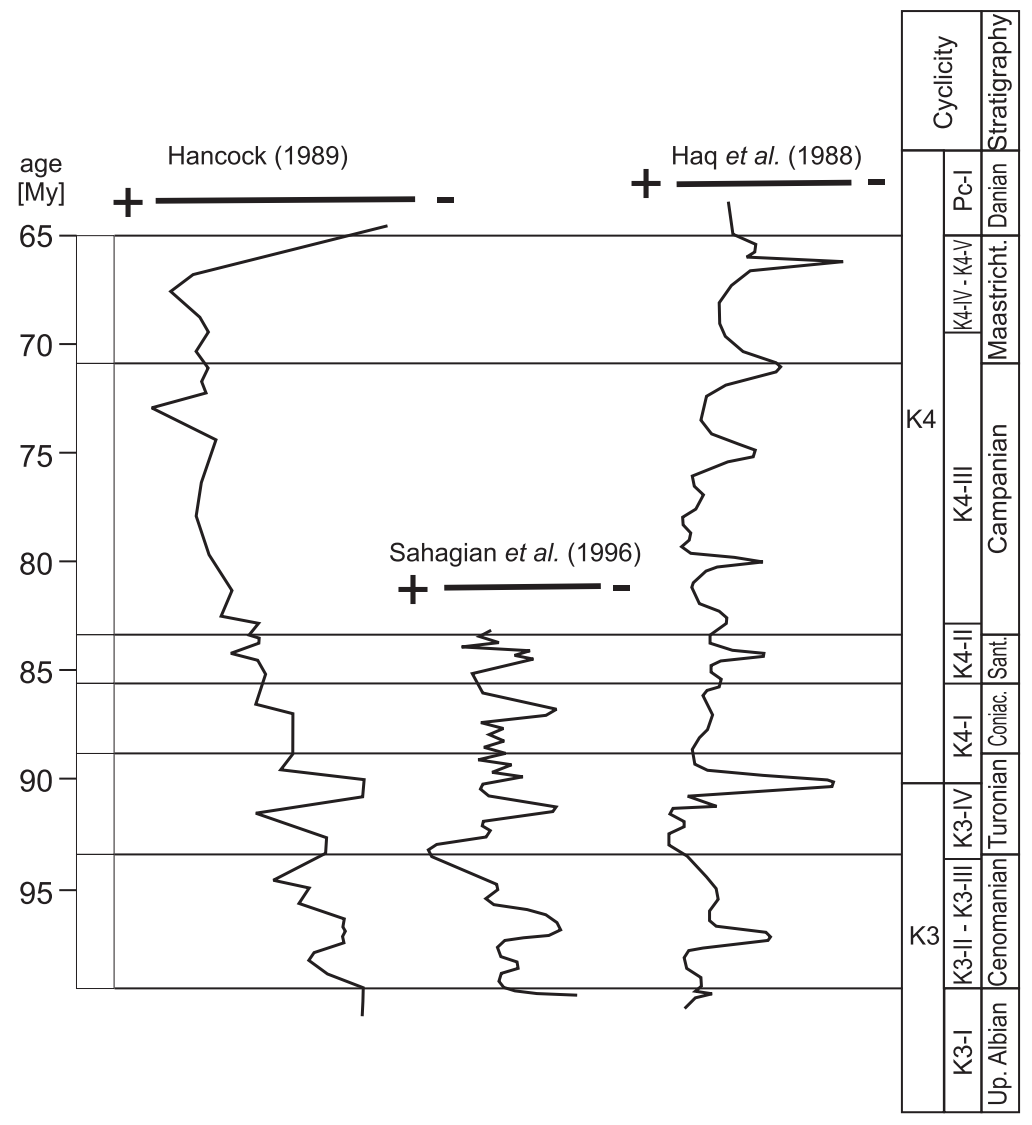

Fig. 2. Late Cretaceous sea level changes

stone (siltstone) $\rightarrow$ sandstone. In the basin centre, siliciclastic facies related to local inversion uplifting movement of salt-cored anticline crests are superimposed on this general lithofacies pattern. The processes of local salt movement and inversion of the Mid-Polish Trough significantly influenced the sea-floor topography and basin bathymetry. An important palaeotectonic and palaeogeographic element was the Koszalin-Chojnice Zone in the Pomeranian Trough. It was a barrier to the siliciclastic facies "expanding" from the Łeba Elevation and Peribaltic Syneclise, especially well-pronounced during Coniacian and Santonian times. A periodic northeastward retreat of the silicilastics and the overlapping position of the Campanian deposits in the Leba Elevation (Dadlez et al., 1976) may have been due to a prominent sea level rise at that time (Fig. 2; Hancock, 1989). The common feature typical of the Upper Cretaceous sequence in the Central European Basin is the occurrence of numerous phosphatic, chert and flint horizons. Nodular phosphates in epicontinental carbonate sequences are indicators of sea level lowstands and may be correlated with troughs on sea level curves, marking a transition from a regressive to transgressive phase (see Hancock, 1989; Marcinowski et al., 1996). There are also numerous hardground surfaces that form as a result of early diagenetic cementation, and document periods of non-deposition or re-exposure and winnowing. Hardgrounds are synsedimentarily lithified carbonate sea-floors that become hardened in situ by the precipitation of carbonate cement in the pri-

from land areas [see Research on Cretaceous Cycles (R.O.C.C.) Group, 1986; Mortimore et al., 2001]. Biogenic limestone sedimentation occurred in areas adjoining the chalk zone. Deeper marine zones were occupied by deposition of pelitic limestones, marls and carbonate-siliceous rocks (predominantly siliceous carbonates - so-called opoka; see Świdrowska and Hakenberg, 1999; Świdrowska et al., 2008). The main factors controlling the sedimentation and lithofacies types were the distance from the shore, topography of land areas and the climate, which was more stable, and of relatively low temperature amplitudes due to large sea areas. However, the relationship between the type of carbonate deposition and the basin depth could also be explained by different rates of calcium carbonate dissolution (e.g., Harapińska-Depciuch, 1972).

The overall lithofacies pattern in the Late Cretaceous basin in Poland is as follows (from deeper to shallower zones): siliceous carbonates (opoka) and pelitic limestone $\rightarrow$ biogenic limestone $\rightarrow$ chalk (Jaskowiak-Schoeneichowa and Krassowska, 1988b; Leszczyński, 2010). Marls could be deposited both in deeper (dissolution of $\mathrm{CaCO}_{3}$ ) and shallower zones extending closer to the land (more terrigenous material). In the areas remaining under the influence of strong clastic supply from the land (e.g., Pomeranian Trough, Łeba Elevation, Peribaltic Syneclise), the following lithofacies zonation is observed: siliceous carbonates (opoka) $\rightarrow$ marly claystone $\rightarrow$ (marly) mud- mary pore space (Wilson and Palmer, 1992). They are common horizons in marine carbonates that exhibit evidence of exposure on the sea-floor as lithified rock. Hardgrounds are often interpreted to mark the tops of regressive sea level changes, or at least to have been followed by transgression (Jones and Desrochers, 1992). However, there are also hardgrounds that form rapidly and are not associated with sea level changes (Dravis, 1979). In the Late Cretaceous basin of the Polish Lowlands, hardgrounds developed due to both regressive pulses related to sea level drops ( $c f$. Hancock, 1989) and uplifting movements of salt-cored anticlines. Increased activity of bottom sea currents could also have played an important role in the process (cf. Hancock, 1989; Rais et al., 2007). Hardgrounds mark the boundaries between the identified individual cycles and have been reported from (i) the Peribaltic Syneclise and Mazury-Suwałki Elevation, (ii) Szczecin Trough, (iii) Płock Trough, (iv) Lublin region and (v) Nida Trough (Krassowska, 1973; Marcinowski, 1974; Jaskowiak-Schoeneichowa., 1979, 1981; Jaskowiak-Schoeneichowa and Krassowska, 1983; Krassowska, 1986; Walaszczyk, 1992; Olszewska-Nejbert, 2004). Hardgrounds are also observed at the top of the Cenomanian succession and in the lower Turonian of the northern and northeastern margin of the Holy Cross Mts. (Cieśliński, 1959; Peryt, 1983; Walaszczyk, 1992). A prominent sedimentary gap, locally represented by a hardground is reported from 


\begin{tabular}{|c|c|c|c|c|c|c|c|}
\hline \multicolumn{6}{|c|}{ Chronostratigraphy } & \multirow{2}{*}{$\begin{array}{c}\text { Sedimentary cyclicity } \\
\text { after } \\
\text { Leszczyński (1997) }\end{array}$} & \multirow{2}{*}{$\begin{array}{l}\text { Inoceramid zonation } \\
\text { after } \\
\text { Walaszczyk (1992) }\end{array}$} \\
\hline \multicolumn{4}{|c|}{$\begin{array}{l}\text { Standard division (Birkelund et al.., 1984; } \\
\text { Rawson et al., 1995) }\end{array}$} & \multicolumn{2}{|c|}{ Błaszkiewicz (1997) } & & \\
\hline 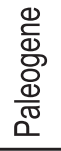 & 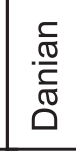 & & & & & Pc-I & \\
\hline \multirow{17}{*}{$\begin{array}{l}0 \\
0 \\
0 \\
0 \\
\frac{\pi}{0} \\
0 \\
0\end{array}$} & \multirow{16}{*}{$\begin{array}{l}\frac{\bar{d}}{0} \\
\frac{0}{2}\end{array}$} & \multirow{2}{*}{ Maastrichtian } & Upper & \multirow{2}{*}{ Maastrichtian } & Upper & K4-V & \\
\hline & & & Lower & & Lower & K4-IV & \\
\hline & & \multirow{2}{*}{ Campanian } & Upper & \multirow{2}{*}{ Campanian } & Upper & \multirow[t]{2}{*}{ K4-III } & \\
\hline & & & Lower & & Lower & & \\
\hline & & \multirow{3}{*}{ Santonian } & Upper & \multirow{3}{*}{ Santonian } & Upper & \multirow{3}{*}{ K4-II } & \\
\hline & & & Middle & & 19 & & \\
\hline & & & Lower & & & & \\
\hline & & \multirow{3}{*}{ Coniacian } & Upper & \multirow{2}{*}{ Coniacian } & & \multirow{4}{*}{ K4-I } & V. involutus \\
\hline & & & Middle & & & & $\begin{array}{l}\text { C. crassus } \\
\text { C. deformis }\end{array}$ \\
\hline & & & Lower & \multirow{4}{*}{ Turonian } & \multirow{2}{*}{ Upper } & & $\begin{array}{l}\text { C. brongniarti } \\
\text { C. waltersdorfensis }\end{array}$ \\
\hline & & \multirow{3}{*}{ Turonian } & Upper & & & & $\begin{array}{r}\text { M. incertus } \\
\text { l. costellatus }\end{array}$ \\
\hline & & & Middle & & \multirow[b]{2}{*}{ Lower } & \multirow[b]{2}{*}{ K3-IV } & $\begin{array}{l}\text { 1. lamarcki } \\
\text { I. apicalis } \\
\text { M hercynicus }\end{array}$ \\
\hline & & & Lower & & & & $\begin{array}{l}\text { M. labiatus } \\
\text { M. kossmati } \\
\text { M. hattini }\end{array}$ \\
\hline & & \multirow{3}{*}{ Cenomanian } & Upper & \multirow{3}{*}{ Cenomanian } & Upper & \multirow{2}{*}{ K3-III } & \\
\hline & & & Middle & & Middle & & \\
\hline & & & Lower & & Lower & K3-II & \\
\hline & $\sum_{0}^{\bar{\phi}}$ & Albian & Upper & Albian & Upper & K3-I & \\
\hline
\end{tabular}

Fig. 3. Upper Cretaceous stratigraphic scheme

C. - Cremnoceramus, I. - Inoceramus, M. - Mytiloides, V. - Volviceramus

the upper Maastrichtian section of the Vistula Gorge near Puławy, WNW of Lublin (Machalski and Walaszczyk, 1987; Peryt, 1988; Hansen et al., 1989; Żarski et al., 1998). Hardgrounds at the Maastrichtian/Danian boundary are also known from some boreholes in the Lublin region (Popiel, 1977; Krassowska, 1986).

Cyclicity of the sedimentation, identified in the Upper Cretaceous-Danian sequence, was controlled by eustatic and tectonic factors. The relationship between the cyclicity and the most commonly used curves of relative sea level changes is illustrated in Figure 2. The boundaries of the cycles are relatively well-correlated with the troughs on the Hancock curve. However, there are also discrepancies between these curves and no close relationships with the cyclicity are visible, which are the result of local/regional tectonics (Figs. 2 and 4).
Previous structural and thickness maps, published and contained in archived materials, were based on data from boreholes and reflection seismic profiles (Dadlez, 1976, 1998; Marek, 1977, 1983; Jaskowiak-Schoeneichowa, 1979, 1981; Krassowska, 1976; Jaskowiak-Schoeneichowa and Pożaryski, 1979; Jaskowiak-Schoeneichowa and Krassowska, 1983; Raczyńska, 1987; Grigelis and Leszczyński, 1998; Leszczyński, 2002a). However, the recently obtained data from new wells and the reprocessed seismic sections provide verification of the stratigraphy in some boreholes, updating those maps and giving possibility for proper interpretations of the basin evolution (e.g., Dadlez, 2001; Krzywiec, 2000, 2002a, b, 2006; Wagner et al., 2002). 


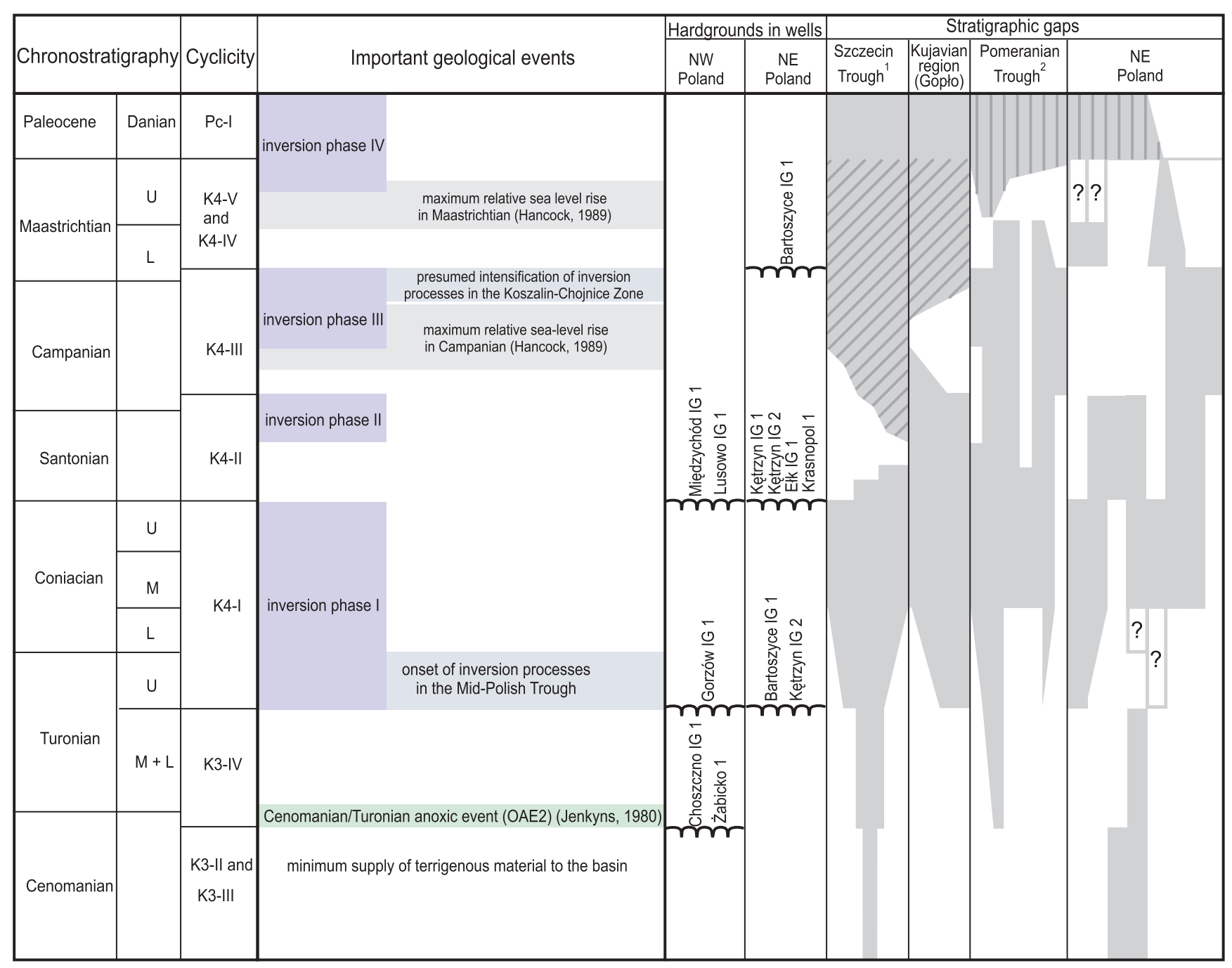

gap

post-Cretaceous erosion

post-Danian erosion

Fig. 4. Late Cretaceous-Danian cyclicity and geological events in the Polish Lowlands

1 - Grzęzno-Człopa-Szamotuły Zone; 2 - Koszalin-Chojnice Zone

\section{GEOLOGICAL DATA \\ AND MAP CONSTRUCTION METHOD}

The materials for constructing the maps are stratigraphic sections of boreholes and data on the relevant thicknesses and depths to the base surface collected from approximately 1100 boreholes (see location map, Fig. 1), including data obtained from detailed lithologic profiling in 780 wells.

The following structural and thickness maps are produced: (1) base Upper Cretaceous contour lines map (Fig. 5); (2) Upper Cretaceous (including Danian) thickness map (Fig. 6); (3) succession K3 (Cenomanian-lower Turonian, excluding cycle K3-I) thickness map (Fig. 7); (4) succession K4 (upper Turonian-Danian) thickness map (Fig. 8).

The Upper Cretaceous thickness map refers to the succession whose boundaries are defined by the depth to the base Up- per Cretaceous (i.e. Albian/Cenomanian boundary) and to the near base Cenozoic (top of the Chalk Group = top Danian), as presented in Doornenbal and Stevenson (2010). The Danian succession, as it pre-dates the ultimate stage of the Mid-Polish Trough inversion and is genetically associated with the Late Cretaceous basin evolution, is included in both the Upper Cretaceous and K4 thickness maps. Compared to the middle Albian/upper Albian boundary, the Albian/Cenomanian boundary is relatively well-defined, based on faunal evidence. It is placed at the last occurrence of Neohibolites minimus (Miller) and abundant occurrence of Aucellina gryphaeoides (Sowerby), which coincides with the last occurrence of foraminifers Globorotalites polonica (Gawor-Biedowa), Marginulina robusta (Reuss) and Pleurostomella reussi (Berthelin) and the first occurrence of Arenobulimina varsoviensis (Gawor-Biedowa) and Tritaxia macfadyeni (Cushman) (Jaskowiak-Schoeneichowa, 1981). 


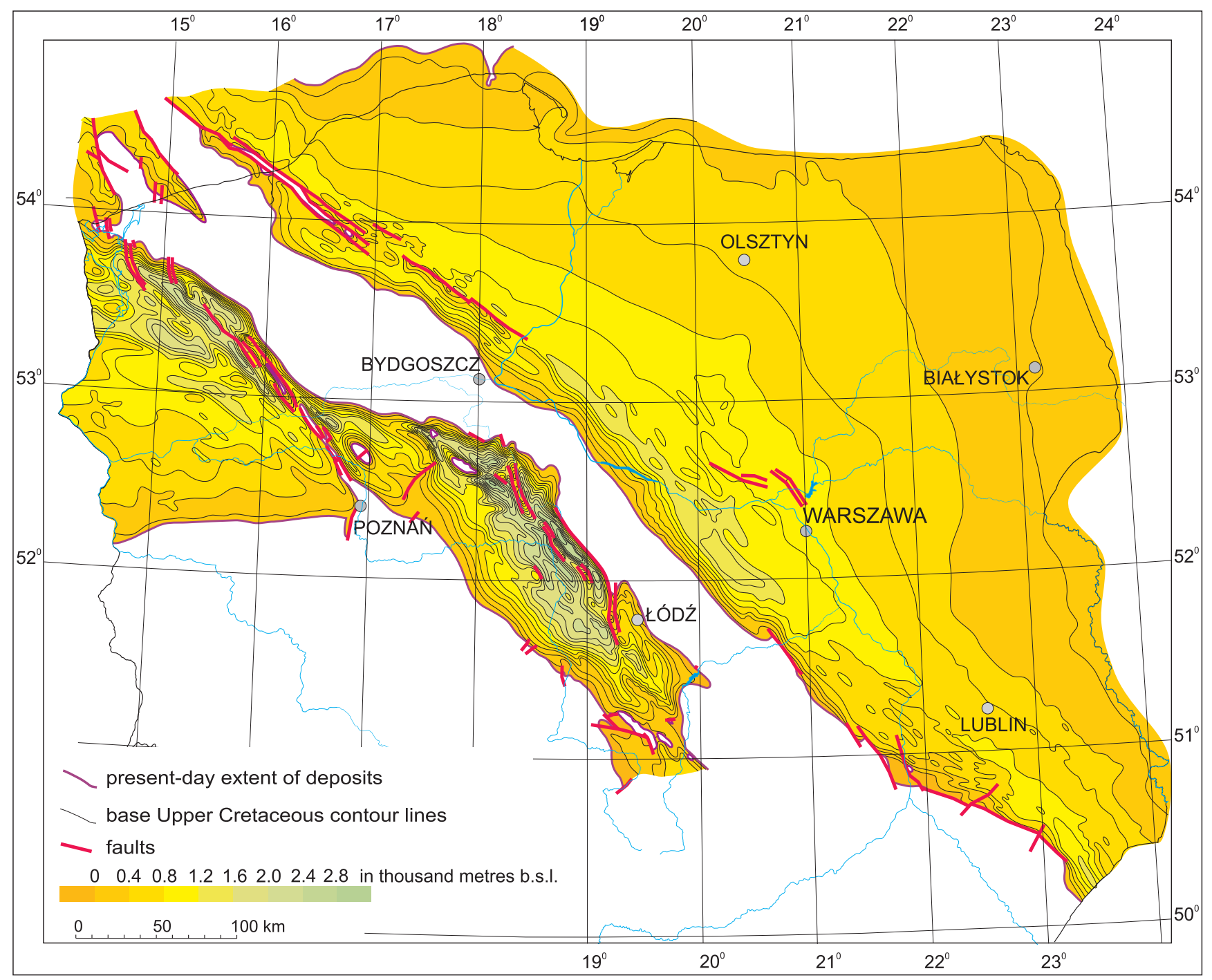

Fig. 5. Base Upper Cretaceous contour lines map

Structural and thickness maps were constructed using a number of subsurface mapping techniques (Kotański, 1971a, 1990). Over most of the study area, where the number of control points is fewer, interpretative contouring (non-equidistant interpolation, equidistant interpolation or combined contouring) was applied. This was the primary technique used for the map construction. In areas with a greater number of control points, "pure" geometric contouring was applied by dividing individual distances between two points into equal sections, based on the equidistant interpolation method. This technique was applied in a few cases.

The structural map (Fig. 5) was constructed based on drilling data (i.e. depth in each well to the base of the Upper Cretaceous) and interpreted seismic sections (Żelichowski, 1971). Contour lines were drawn after analysing all available geological data from boreholes and geophysical studies (reflection seismics), and taking into account other data, such as regional tectonic setting, on the geological structure of individual areas. Thus, the outlines of anticlines and synclines were contoured so that the structures were consistent with the regional trends and with the image interpreted from reflection seismic sections. The outlines and contours for individual structures in the structural and thickness maps were subsequently compared, verified, slightly modified and corrected in some areas according to the images proposed by B. Papiernik (in: Doornenbal and Stevenson, 2010) and produced using the Z-map mapping software. Nevertheless, most of the author's own interpretations have been retained. The base Upper Cretaceous structural map can be considered a map that images an equi-temporal surface (base of the Cenomanian).

The cartographic images for the Germany/Poland borderland in the structural and thickness maps were jointly produced in association with German geologists within the framework of the international research project entitled "Petroleum Geological Atlas of the Southern Permian Basin Area" (Doornenbal and Stevenson, 2010).

A combined technique was applied for the construction of thickness maps, using a superposition method (Kotański, $1971 b$ ), directly from data acquired from boreholes, and interpreted seismic sections. It should be noted, however, that the 


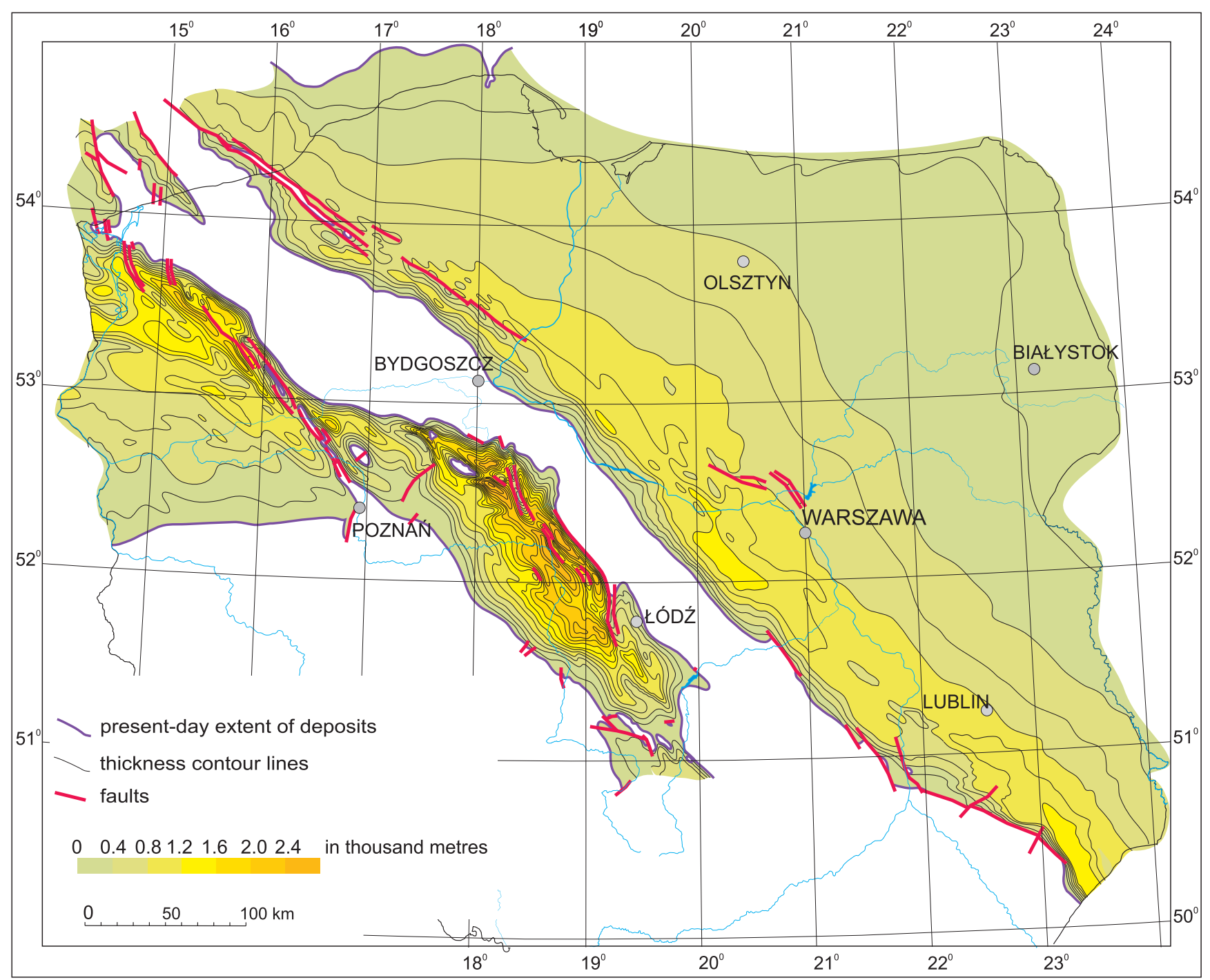

Fig. 6. Upper Cretaceous (including Danian) thickness map

thicknesses represent apparent thickness values (isochore maps) calculated in boreholes between the basal and top surfaces. Due to commonly low dips in the Cretaceous strata $\left(<10^{\circ}\right)$ and the large map scale, it can be assumed, therefore, that the mapped thicknesses more or less correspond to actual thickness values (isopach maps). The thickness maps for successions K3 and K4 (as defined in terms of the Cretaceous cyclicity proposed by Leszczyński, 1997; Fig. 3) are constructed using data from 554 boreholes in which the position of the $\mathrm{K} 3 / \mathrm{K} 4$ boundary has been established relatively reliably. These maps illustrate the post-inversion geometry of the basin for the pre-inversion (Cenomanian-lower Turonian), and for the syn-inversion successions (upper Turonian-Danian). Since all the maps are constructed with respect to the standard lower boundary of the Upper Cretaceous series, cycle K3-I (upper Albian) is not included in succession K3. Thus, succession K3 is understood hereafter as representing only cycles $\mathrm{K} 3$-II to K3-IV (Fig. 3). The contour line intervals on the maps are drawn as follows: base of the Upper Cretaceous map and Upper Cretaceous (including Danian) thickness map - every 200 m; succession K3 map - every 50 m; succession K4 (including Danian) map - every $200 \mathrm{~m}$.

The lithofacies pattern identified in the Late Cretaceous basin of the Polish Lowlands is presented in seven maps created for eustatically and tectonically controlled cycles (see Leszczyński, 1997, 2002a). These cycles and their associated maps are presented in Figures 9 to 15. The lithofacies pattern in areas where Upper Cretaceous deposits have been eroded due to inversion (Mid-Polish Swell, NE Fore-Sudetic Monocline) is interpreted based on regional lithofacies pattern and local tectonics.

Previously published lithofacies maps were constructed at smaller scales (Jaskowiak-Schoeneichowa and Krassowska, $1988 b$; Krassowska, 1997). They were compiled from the original 1:500 000 scale maps available only as an archived report and were constructed for each Cretaceous stage (JaskowiakSchoeneichowa and Krassowska, 1988a). A further modification has been the use of qualitative reconstructions of generalized lithofacies types (associations) with the dominant lithofacies component and accessory components indicated. 


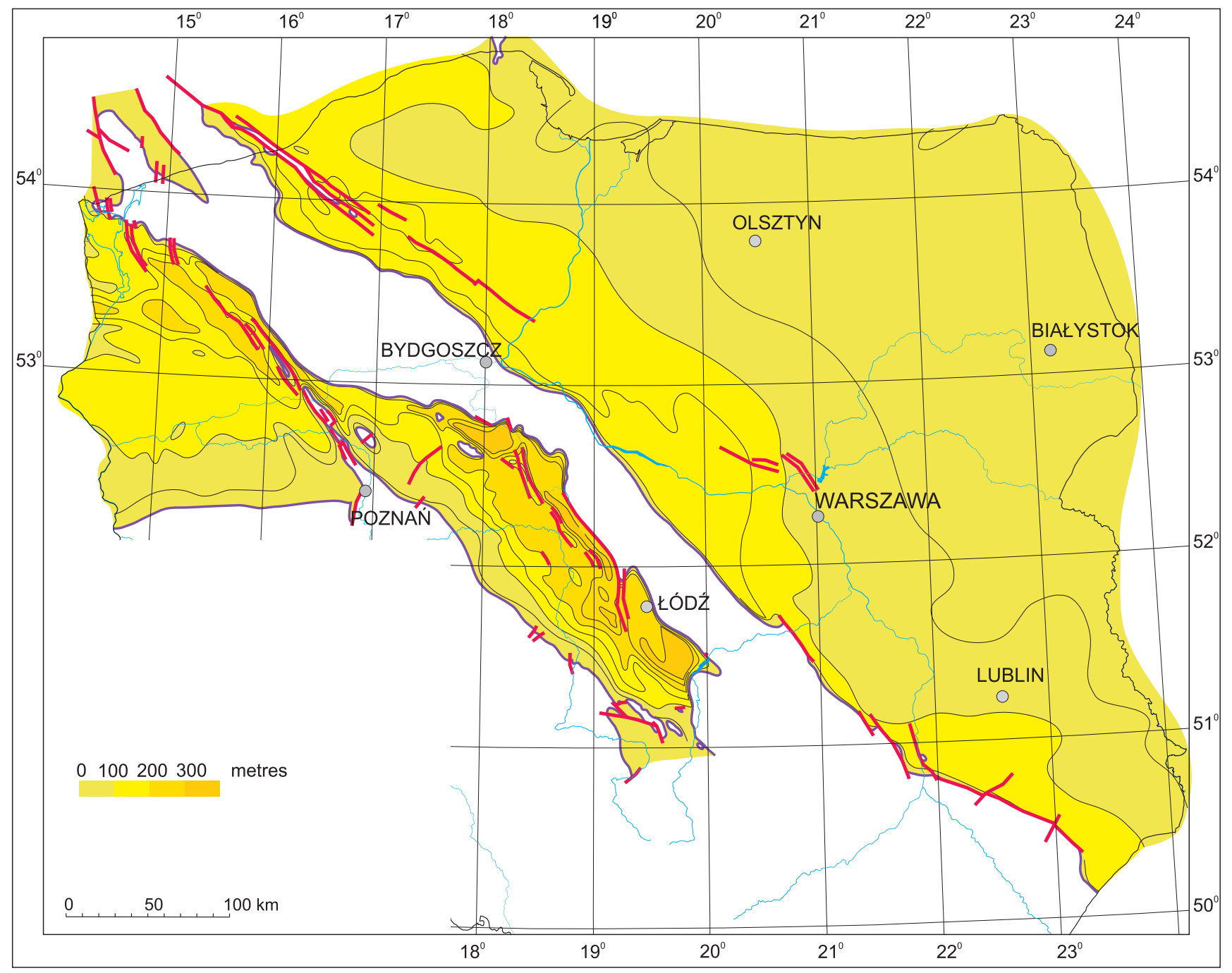

Fig. 7. Succession K3 (Cenomanian-lower Turonian, excluding cycle K3-I) thickness map

For explanations see Figure 6

Using this approach, an analysis of lithology, mainly from borehole wireline-logs has been used in the construction of lithofacies maps. An example of a generalized correlation chart of the Upper Cretaceous-Danian succession for some boreholes is presented in Figure 16. During his many-year research, the author verified and reinterpreted the lithology and stratigraphy of the Upper Cretaceous sections from a number of boreholes (e.g., Gościejewo 2, Damasławek 20). In particular, special emphasis has been placed on recognizing hardgrounds, sedimentary breaks and any signs of cyclicity within the succession. As a result, previously incorrect correlations between corresponding lithological complexes have been corrected. Detailed analysis of available borehole data enabled recognizing transgressive and regressive events using hardgrounds, nodular phosphates, gaps etc., and establishing the stratigraphic position of each event.

In reconstructing the lithofacies patterns, a qualitative approach has been applied, showing the dominant lithological component (underlined) accompanied by subordinate ones. In carbonate-dominated sequences, the transitions between individual rock types are often gradual, e.g.: chalk $\rightarrow$ marly chalk $\rightarrow$ chalk-like limestone $\rightarrow$ limestone $\rightarrow$ marly limestone $\rightarrow$ marl $\rightarrow$ opoka (siliceous carbonates) $\rightarrow$ gaize (carbonate-siliceous rock of sedimentary origin, fine grained and porous due to content of sponge spicules). Such gradual transitions make it difficult to provide quantitative illustrations of lithofacies types. In order to maintain a clear picture of the lithofacies pattern in the maps, each lithofacies area consists of up to three lithofacies types. The percentage contribution of each lithofacies type is commonly at least $25 \%$, although there are some deviations from the rule if a specific lithofacies type needs special emphasis. The term "lithofacies" is a descriptive one, understood as an association of rock types showing related lithological features.

Nine lithofacies types associations, corresponding to specific sedimentary environments and depositional systems, are 


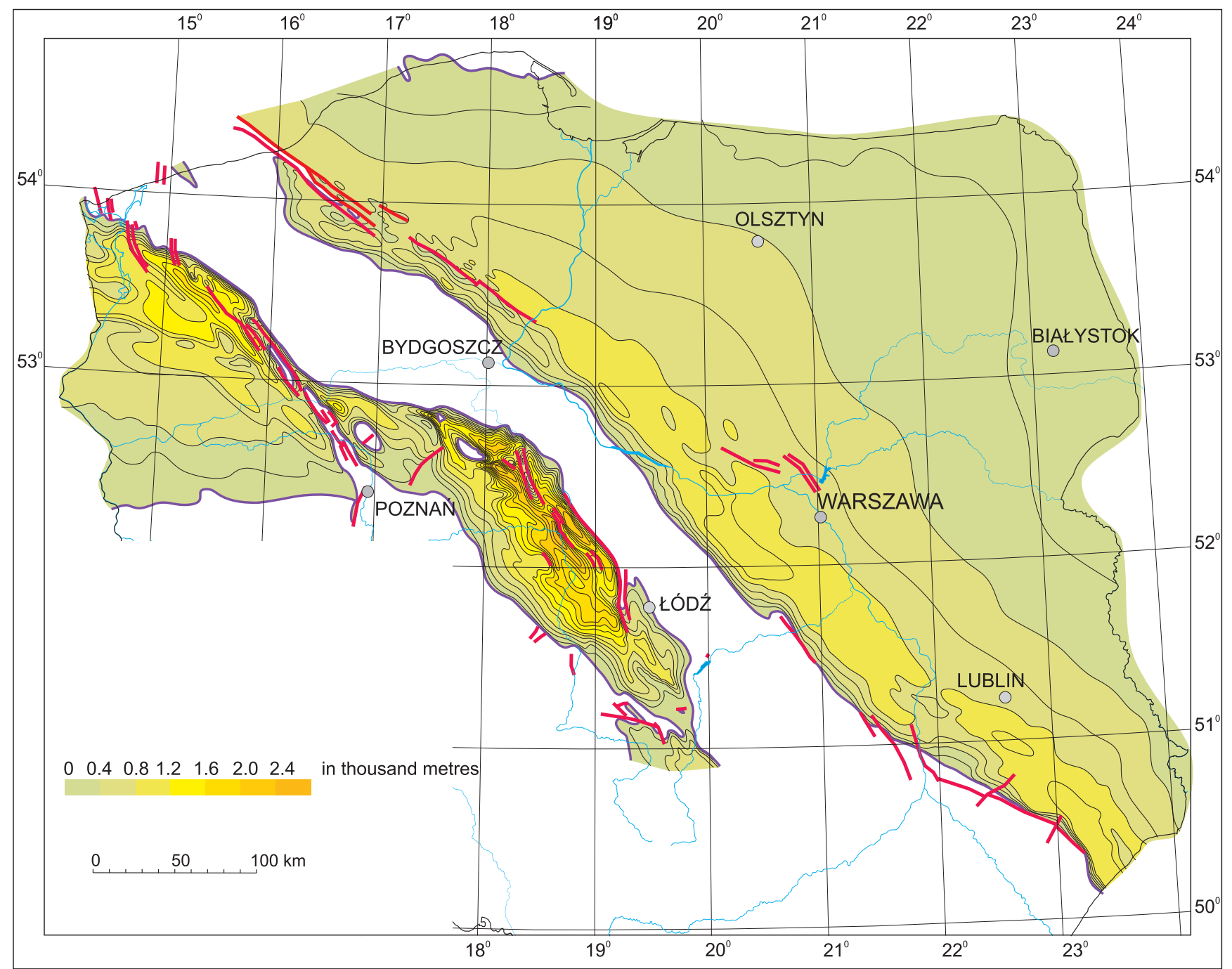

Fig. 8. Succession K4 (upper Turonian-Danian) thickness

For explanations see Figure 6

proposed for the Upper Cretaceous succession of the Polish Lowlands (the dominant lithological components are in bold):

1. Chalk lithofacies - chalk/marly chalk, local chalk-like limestone and pelitic limestone (open-marine pelagic zone, carbonate shelf);

2. Carbonate (limestone) lithofacies - pelitic limestone/organogenic limestone/marly limestone, local marl, and chalk-like limestone (open-marine pelagic zone, carbonate shelf);

3. Marly lithofacies - marl, local marly limestone, opoka interbeds (open-marine pelagic zone, carbonate (marly) shelf);

4. Carbonate-siliceous lithofacies - opoka (siliceous carbonates), local gaize, subsidiary marl (open-marine pelagic zone, carbonate-siliceous shelf);

5. Clay-marly lithofacies - marly claystone, clayey marl (siliciclastic-carbonate shelf);

6. Muddy (silty)-marly lithofacies - marly mudstone (siltstone), silty (muddy) marl (siliciclastic-carbonate shelf);
7. Muddy-sandy-marly lithofacies - sandy-marly mudstone (siltstone), muddy (silty)-sandy marl, sandy-marly limestone, sandy marl, sandy gaize interbeds (siliciclastic-carbonate shelf);

8. Sandstone lithofacies - sandstone/marly sandstone, mudstone (siltstone)/marly mudstone interbeds (siliciclastic shelf);

9. Sandy carbonate lithofacies - sandy limestone, local sandy marl and sandy gaize (siliciclastic-carbonate shelf).

In total, 54 single-type and mixed-type lithofacies (lithofacies association) areas have been presented in the maps (see legend in Fig. 9). Chalk lithofacies, as a very distinctive rock type of the Late Cretaceous basin, has been singled out from carbonates as a separate lithofacies. A carbonate-sandy lithofacies has been distinguished as a characteristic facies type represented by transitional rocks from limestones to sandstones: sandy limestones and calcareous sandstones, especially widespread in the Maastrichtian. The so-called muddy-sandymarly lithofacies represented by sandy-marly mudstones and 
siltstones with sandy to silty marl, and sandy limestone, marl and gaize interbeds is also recognized. The Upper Cretaceous and Danian sandstones usually contain calcium carbonate.

Marl is an important constituent predominantly in areas dominated by carbonate and carbonate-siliceous lithofacies (2 and 3). Marls occur as interbeds, normally accounting for less than $25 \%$ of the total thickness.

The lithofacies pattern of the Maastrichtian (locally also of the Campanian and older stages) is incomplete due to post-Cretaceous erosion. However, the lithofacies zones displayed on the Maastrichtian map are extended by interpreting the missing part of the section. As a result, the actual lithofacies picture may differ from the version presented. In the lithofacies maps, the interpretation for areas of complete or partial erosion (Mid-Polish Swell) is based on palaeogeographical and tectonic models and possible scenarios for lithofacies development.

\section{MAIN FEATURES OF THE INTERNAL GEOMETRY}

The general features and trends visible in the base Upper Cretaceous contour lines map (Fig. 5) and in the Upper Cretaceous (including Danian) thickness map (Fig. 6) are similar to those presented in the previous versions of structural and thickness maps constructed for individual regions. However, a number of specific differences, clarifications and updates have been made in many areas where new boreholes have been drilled and good-quality seismic sections have been acquired. Hence, there are some modifications in the picture of the number of synclinal and anticlinal structures.

The greatest depth to the base of the Upper Cretaceous is in the Kujavian segment of the Mid-Polish Trough. These zones are also areas of the greatest thickness of Upper Cretaceous deposits. In the Mogilno and Szczecin troughs, the basal Upper Cretaceous surface shows the most varied structural relief and the thicknesses display considerable variability and steeper gradients.

A way of investigating sedimentation rates in relation to structure is to compare the ratio of the maximum thicknesses of successions K3 and K4 from the area situated to the SW of the present-day Mid-Polish Swell to the maximum thicknesses of these successions from the area located to the NE of it (calculated individually for the Pomeranian and Kujavian segments). The maximum thickness ratio calculated for succession $\mathrm{K} 3$ is approximately 1.75 (350/200 metres) in the Kujavian segment, and approximately 1.25 (250/200 metres) in the Pomeranian segment, whereas the maximum thickness ratio calculated for succession K4 is approximately 2.25 (2700/1200 metres) in the Kujavian segment, and approximately 1.9 (1700/900 metres) in the Pomeranian segment. If succession K3 is considered as including cycle K3-I (upper Albian), then the values are about 1.85 and 1.35. In the case of K4, the volume of eroded Maastrichtian deposits should be taken into account, but then the ratio would be slightly higher because the quantity of sediments removed from the SW area was probably greater.

The ratio of the maximum thicknesses of successions K3 and $\mathrm{K} 4$ from the area situated to the SW of the present-day
Mid-Polish Swell to the maximum thicknesses of these successions from the area located to the NE of it was calculated separately for the Pomeranian and Kujavian segments. The calculated values are greater for succession $\mathrm{K} 4$ by a factor of $\sim 1.28$ and $\sim 1.52$, respectively for the Kujavian and Pomeranian segments. If succession $\mathrm{K} 3$ is considered as including cycle K3-I (upper Albian), then the values are slightly lower: $\sim 1.22$ and $\sim 1.41$. The thickness ratios between anticlinal and synclinal zones are also clearly higher for succession K4 than for succession K3. This indicates a greater difference in subsidence rate between the areas extending on the two sides of the present-day Mid-Polish Swell during deposition of succession K4 than during deposition of succession K3, with a much higher subsidence in the SW area during deposition of succession K4.

In the area located to the NE of the Mid-Polish Swell, succession K4 is also thicker in the Kujavian and Lublin segments (over $1000 \mathrm{~m}$ ) than in the Pomeranian segment (over $800 \mathrm{~m}$ in the Lower Vistula region and over $600 \mathrm{~m}$, south of Koszalin in the Pomeranian Trough). Succession K3 attains the greatest thickness in the Pomeranian and Kujavian segments (approximately $200 \mathrm{~m}$ ), whereas in the Lublin region the values are lower (around $100 \mathrm{~m}$ ). These thicknesses show that the zone of maximum subsidence migrated SE-wards in the Late Cretaceous from the Pomeranian and Kujavian segments towards the Kujavian and Lublin segments.

\section{REMARKS ON BASIN SUBSIDENCE AND BATHYMETRY}

The Cenomanian sea level rise caused the deepening of seas and basinwide development of carbonate sedimentation (including chalk deposition) in most of the European basins (Hancock and Kauffman, 1979; Haq et al., 1988; Hancock, 1989). It has been commonly assumed that the depth at which the Late Cretaceous pelagic carbonate sequences were deposited varied from 100 to $500 \mathrm{~m}$ (Research on Cretaceous Cycles (R.O.C.C.) Group, 1986; Mortimore et al., 2001), although greater values were also suggested (Hancock and Kauffman, 1979; Tucker and Wright, 1990). Assuming both a high stand of sea level for the Late Cretaceous period (Hancock and Kauffman, 1979; Ziegler, 1982; Haq et al., 1988; Hancock, 1989) and a maximum depth of the Cenomanian sea in the Mid-Polish Trough at over $100 \mathrm{~m}$, the calculated tectonic subsidence rate appears to be still low $(<30 \mathrm{~m} / \mathrm{Ma})$. This was only slightly different from that observed during Early Cretaceous times, where the tectonic subsidence rate was up to approximately $30 \mathrm{~m} / \mathrm{Ma}$ (Dadlez et al., 1995, 1998; Leszczyński, 2002a). The Turonian sea was probably deeper (200-400 m) and the Turonian-Coniacian tectonic subsidence rate abruptly increased to over $200 \mathrm{~m} / \mathrm{Ma}$ (Leszczyński, $2002 a$ ), however, not reaching values as high as during the earlier history of the Mid-Polish Trough (Dadlez et al., 1995, 1998; Stephenson et al., 2003). Salt movements that intensified from the late Turonian-Coniacian onwards resulted in the formation of deeper and shallower zones within the basin (Cieśliński and Jaskowiak, 1973).

The basin depth varied from zone to zone, controlled by local tectonic setting. The sea was deeper in synclinal areas (salt 
withdrawal) and shallower (above the wave base) over rising anticlinal crests even with local emergence above sea level (rapidly rising salt stocks).

Based on sponge investigations, Świerczewska-Gładysz (2006) interpreted the maximum depth of the late Campanian basin in the Middle Vistula region at 200-250 m, and the minimum depth of the latest Maastrichtian basin (siliceous marl facies) at about $100 \mathrm{~m}$.

Macrofaunal research led Abdel-Gawad (1986) to the conclusion that siliceous marl of the Puławy region was deposited in a pelagic environment at a depth between 100 and $150 \mathrm{~m}$.

Chalk sedimentation in Eastern Poland took place in a relatively shallow marine environment, but below storm wave-base. Siliciclastic deposits were accumulated in shallow shelf marginal zones of the basin.

\section{PROBLEM OF TECTONIC INVERSION OF THE MID-POLISH TROUGH}

The mechanism and timing of tectonic inversion of the Mid-Polish Trough is still disputed. Some authors claim that the main phases of inversion occurred after the Cretaceous and its earliest signs should be dated at the Maastrichtian (e.g., Kutek and Głazek, 1972; Świdrowska and Hakenberg, 1999; Świdrowska, 2007). The other concept assumes that the inversion was a multi-phase process triggered during the (?)latest Turonian-Coniacian (Dadlez, 1976, 1980; Dadlez et al., 1997; Jaskowiak-Schoeneichowa, 1981; Krassowska, 1997; Dadlez and Marek, 1997; Leszczyński, 1997, 2000; Leszczyński and Dadlez, 1999; Krzywiec, 2000, 2002a, b, 2006; Resak et al., 2008; Krzywiec et al., 2009). Analysis of seismic data suggests the following general inversion phases: late Turonian-Coniacian, late Santonian-Campanian and late Maastrichtian-Paleocene (Krzywiec, 2006).

Inversion processes triggered reactivation of pre-existing synsedimentary faults as reverse faults (see Świdrowska and Hakenberg, 1999) often accompanied by spectacular salt structures in the form of salt stocks and walls (e.g., Damasławek and Kłodawa salt diapirs). Intensity of halotectonic deformation in the area presently devoid of Upper Cretaceous deposits (Pomeranian and Kujavian swells) increases from NW to SE (Dadlez, 1980). The most prominent salt bulges (pillows) are observed within the Prady, Szubin, Ciechocinek and Jeżów structures located in the central and NE parts of the Mid-Polish Swell (see Dadlez, 2001). However, there is no evidence that the structures were sources of clastic material transported to the nearby basinal zones (Płock and Pomerania troughs). The inversion process was especially intense along the SW margin of the present-day Mid-Polish Swell (Fig. 1, units 8 and 9), resulting in uplift movements along the areas adjoining the then-forming Szczecin, Mogilno and Uniejów troughs. The troughs were the areas of higher subsidence rate giving rise to considerable thicknesses of Santonian-Campanian deposits in synclinal zones. Both salt-cored and non-salt anticlinal zones were subjected to inversion. The most spectacular example of a non-salt inverted structure is the Koszalin-Chojnice Zone where mid-Late Cretaceous stratigraphic gaps have been proven (Jaskowiak-Schoeneichowa, 1976; Dadlez, 2001; Leszczyński, 2002b). Relations between these stratigraphic gaps and the cycles and the position of hardgrounds in NW and NE Poland are shown in Figure 4. Tectonic activity is observed especially within the Mid-Polish Trough. Analyses of the strings of tectonic zones of Grzęzno-Człopa-Szamotuly (NW of Poznań, at the boundary of the Szczecin and Mogilno troughs), Damasławek-Mogilno, Gopło and Kłodawa (Central Poland), supported by examination of the facies pattern around them and along the slope of the present-day Mid-Polish Swell, indicate tectonic activity first developing markedly in the north-west (in the Turonian) and then moving towards the south-east (Kłodawa - in the Santonian).

Interpretation of reflection seismic data from the NE marginal fault zone (Nowe Miasto-Zawichost) of the Holy Cross segment of the Mid-Polish Trough also indicates inversion of this sector already happening in the late Turonian (Dadlez et al., 1995; Gutowski et al., 2003; Krzywiec et al., 2009).

Seismic reflection facies interpreted as "debris flows" originating from the crests of rising anticlinal axes were also reported from the Danish Basin (Liboriusen et al., 1987). The uplift started there during the Coniacian and rapidly accelerated during Santonian-Campanian times. Local influx of clastics (sand) in the Bornholm area indicates that the anticlinal crests were exposed to the sea level, forming elongated zones during the latest Cretaceous-earliest Paleogene (Surlyk, 1980). Worth mentioning are also quartzose sands of the Lund Sandstone in Scania, described by Erlström (1990).

Palaeogeographic reconstructions and basin modelling suggest that inversion processes resulted in a removal of some 1 to over $2 \mathrm{~km}$ of Upper Cretaceous deposits from the Mid-Polish Swell, and the base of Zechstein was elevated even by $4 \mathrm{~km}$ in the Kujavian segment (Dadlez et al., 1997; Dadlez, 2001; Wagner et al., 2002; Resak et al., 2008). Deeply rooted fault systems, e.g., the Koszalin-Chojnice, Drawno-Człopa-Szamotuly and Gopło-Ponętów-Wartkowice zones, were active during the sedimentation and played a significant role in the lithofacies distribution (Dadlez and Marek, 1974; JaskowiakSchoeneichowa, 1976; Leszczyński, 2002a, b). The Late Cretaceous sedimentation was also controlled by the faults recorded within the basement in SE Poland (Hakenberg and Świdrowska, 1998; Świdrowska, 2007). Another factor controlling the facies distribution pattern was the process of withdrawal of Zechstein salt from synclinal areas, active throughout the Cretaceous but intensified from the Coniacian onwards (Cieśliński and Jaskowiak, 1973; Leszczyński, 2000).

The Late Cretaceous-early Paleogene structural inversion of the Mid-Polish Trough is widely discussed in recent papers by Mazur et al. (2005), Krzywiec (2006), Resak et al. (2008) and Krzywiec et al. (2009). 


\section{LITHOFACIES DEVELOPMENT}

\author{
CYCLES K3-II-K3-III \\ (EARLY CENOMANIAN-EARLY LATE CENOMANIAN) \\ (FIG. 9)
}

Over much of the Polish Lowlands, especially in N, NE and E Poland, the early Cenomanian sedimentation (mostly glauconitic sandstones with phosphatic horizons) occurred on a shallow siliciclastic and siliciclastic-carbonate (sandy-carbonate) shelf. Phosphatic horizons and local hardgrounds are reported from the Lublin region (e.g., Krassowska, 1981, 1986), Pomerania (Jaskowiak-Schoeneichowa, 1976), northern Nida Trough and Holy Cross Mts. margin (Cieśliński, 1976; Hakenberg and Świdrowska, 1998). As the marine transgression continued, the facies changed to open marine marls and carbonates represented mostly by organogenic and pelitic limestones.

In the Leba Elevation, Peribaltic Syneclise and Mazury Elevation, marly, muddy-marly and clay-marly lithofacies grade into muddy-sandy-marly and sandy lithofacies with predominant sandstones and local wackes and arkosic wackes. Clastic material is most likely to have been derived from land areas of the Baltic Shield. The chalk lithofacies is observed only in the Wolin Island region, NW Poland. Succession K3-II-K3-III represents a general trend of continuously deepening sedimentary basin from shallow shelf siliciclastic and siliciclastic-carbonate deposition to open-marine carbonate shelf deposition.

\section{CYCLE K3-IV (LATEST CENOMANIAN-EARLY TURONIAN) (FIG. 10)}

Succession K3-IV is characterized by retreat of siliciclastic lithofacies from northeastern Poland (Fig. 10), being replaced by carbonate and chalk facies. Carbonate-siliceous lithofacies (opokas) is widely developed, mainly in the Szczecin and Mogilno troughs along the slope of the present-day Mid-Polish Swell, and in the Płock Trough. In the northeastern part of the Szczecin Trough and in the Pomeranian Trough, clay-marly and muddy-marly sedimentation prevailed. Muddy-marly and muddy-sandy-marly lithofacies are dominant towards the NE (Łeba Elevation and Peribaltic Syneclise) with a higher proportion of sand and sandy-glauconitic facies (JaskowiakSchoeneichowa, 1976). Sandstone lithofacies with glauconite are observed in the Peribaltic Syneclise (Gulf of Gdańsk) (Jaskowiak-Schoeneichowa, 1976). To the NE of Olsztyn, there is a small non-deposition area, probably an island surrounded with siliciclastic deposition, predominantly sandstones and fine-grained siliciclastics. In that region, this very thin cycle is capped by a hardground (e.g., Bartoszyce IG 1, Kętrzyn IG 2). Local influx of clastic material (clay-marly and muddy-marly lithofacies) is observed in the Szczecin Trough (probably related to halotectonic activity of the Grzęzno-Człopa Zone).

Carbonate sedimentation of organogenic and pelitic limestones occurs in the Gorzów Block and along the margin of the Fore-Sudetic Monocline (Jaskowiak-Schoeneichowa, 1979,
1981). Carbonates also predominate in the Mogilno-Uniejów Trough as far as the Nida Trough (Mrozek, 1975; Hakenberg, 1978, 1986). In the Mogilno and Uniejów troughs, they are accompanied by marly lithofacies (Jaskowiak-Schoeneichowa, 1972, 1977; Leszczyński, 2002a). The area extending from the Olsztyn region towards the S and SE (across central Mazowsze and the Lublin region) is again a wide belt of dominantly open-marine carbonates represented mostly by organogenic and pelitic limestones. Carbonate-siliceous lithofacies (opoka) are more common in the Lublin Trough close to the slope of the present-day Mid-Polish Swell.

Eastern and northeastern Podlasie and the eastern Lublin region (along the east border of Poland) are the areas of calm pelagic sedimentation of chalk and chalk-like limestones (Krassowska, 1976, 1997). Over a large area of the Szczecin, Mogilno and Uniejów troughs, close to the slope of the present-day Mid-Polish Swell, thin black shale layers are observed within a mudrock series at the Cenomanian/Turonian boundary (Jaskowiak-Schoeneichowa, 1972, 1977, 1987; Leszczyński, $2002 a$ ). These rocks show features of a deposit accumulated in a preferentially oxygen-depleted zone of the basin, and may be correlative with the so-called Oceanic Anoxic Event 2 also called the Bonarelli Event (e.g., Schlanger and Jenkyns, 1976; Jenkyns, 1980; Arthur et al., 1987). Similar deposits have been reported from the Lower Saxony Basin, Germany (Hilbrecht and Dahmer, 1994) and from many basins worldwide. A possible cause of the event was strong magmatic activity and sub-oceanic volcanism (Kump et al., 2005; Turgeon and Creaser, 2008). It resulted in an abrupt rise in temperature, induced by rapid influx of $\mathrm{CO}_{2}$ into the atmosphere from volcanogenic and/or methanogenic sources, followed by increase in organic productivity. The consumption of the newly abundant organic life by aerobic bacteria produced anoxia that could be the reason for extinction of many species (Schlanger and Jenkyns, 1976; Kerr, 1998). The deposits show elevated TOC and $\delta^{13} \mathrm{C}$ values, and enrichment of trace elements (e.g., Brumsack, 1986; Schlanger et al., 1987; Peryt et al., 1994; Jones and Jenkyns, 2001).

\section{CYCLE K4-I (LATE TURONIAN-CONIACIAN) (FIG. 11)}

Carbonate-siliceous lithofacies (various types of opokas see Jaskowiak-Schoeneichowa, 1981) are very common in cycle K4-I, covering large areas (Fig. 11), including the Szczecin, Mogilno and Uniejów troughs, as well as the Lower Vistula region. South-west of the carbonate-siliceous zone, marly and carbonate lithofacies occur in the Gorzów Block and along the Polish/German border (Jaskowiak-Schoeneichowa, 1979). Close to the SW slope of the present-day Mid-Polish Swell, siliciclastic facies are locally found in the Mogilno and Uniejów troughs, as a response to the rising crests of salt-cored anticlines (Jaskowiak-Schoeneichowa, 1972, 1977, 1987).

On both sides of the Pomeranian Swell (in the Pomeranian and Szczecin troughs), there is an area of carbonate-siliceous deposition (silty opoka; Jaskowiak-Schoeneichowa, 1976). It may imply that similar facies extended also between these two areas. In the Koszalin-Chojnice Zone, the lithology changes to 


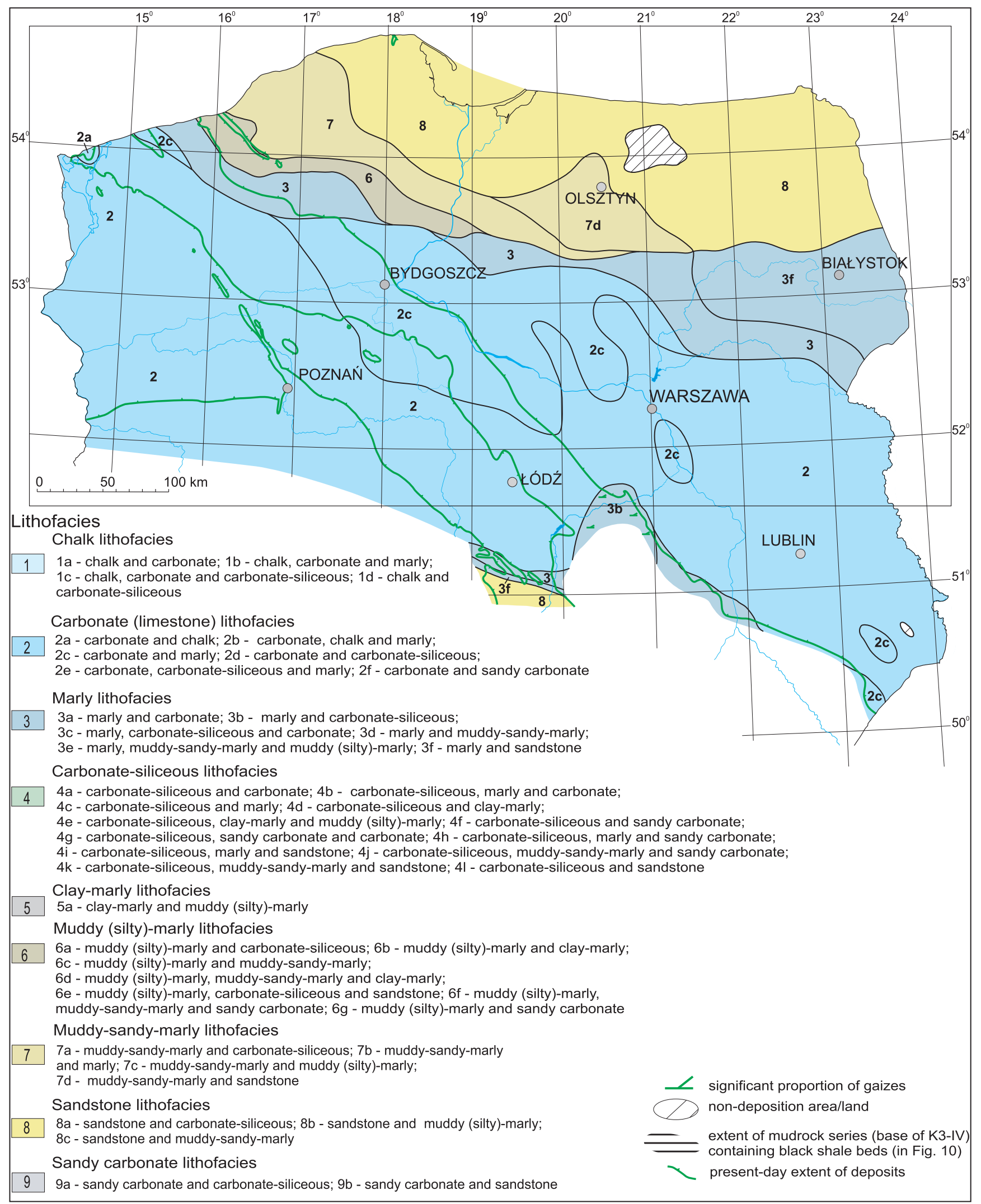

Fig. 9. Cycle K3-II-K3-III (early Cenomanian-early late Cenomanian) lithofacies 


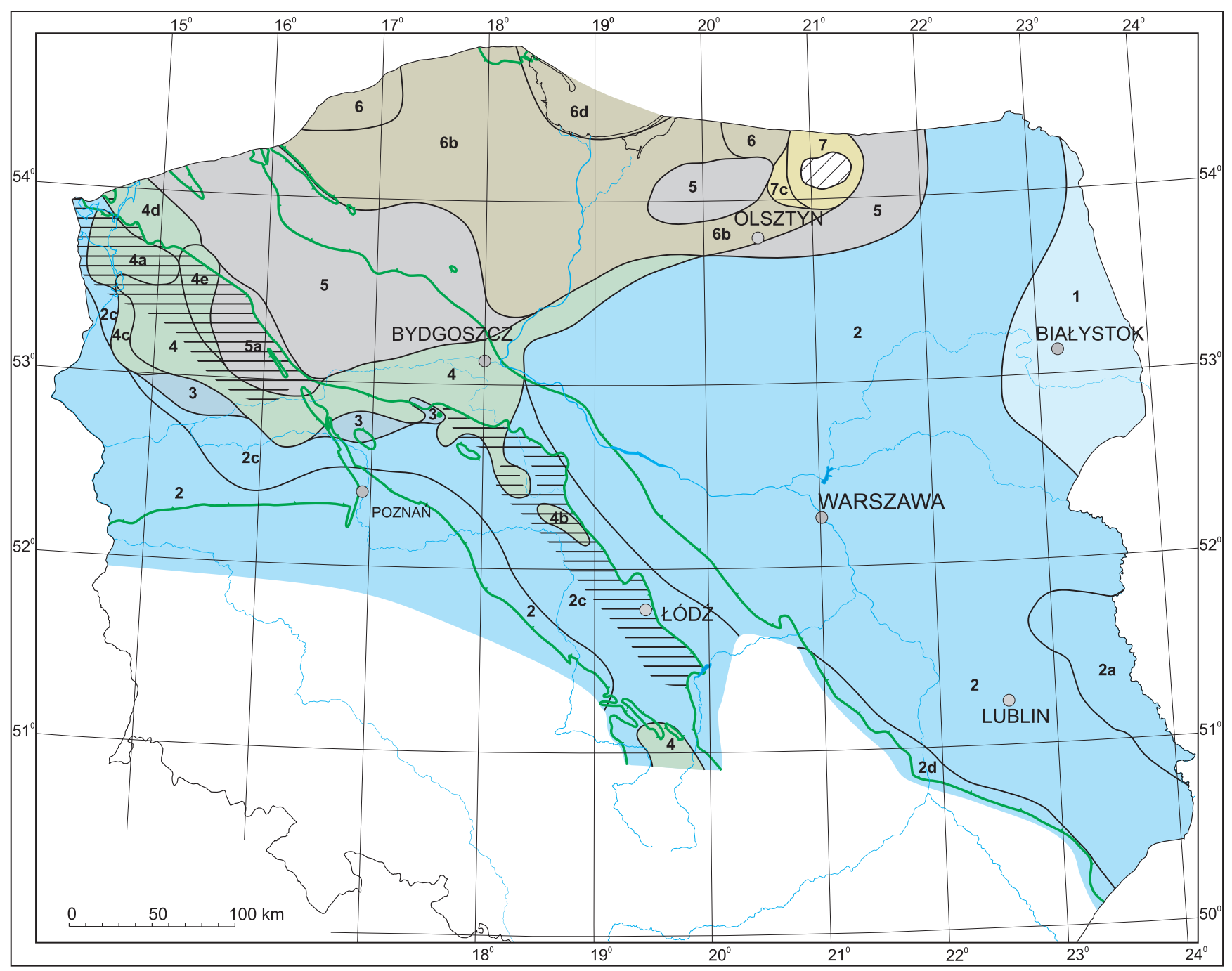

Fig. 10. Cycle K3-IV (latest Cenomanian-early Turonian) lithofacies

For explanations see Figure 9

muddy-marly lithofacies that extend as far eastwards as the Vistula Lagoon (Leszczyński, 2002b). The upper part of the succession in this region (probably corresponding to the Coniacian) is composed of carbonate-siliceous lithofacies. In the south-east of the Pomeranian Trough, the upper Turonian is represented by muddy-sandy-marly lithofacies, whereas the inferred Coniacian interval is composed of opokas.

Muddy-sandy-marly and sandstone lithofacies predominate in the Łeba Elevation and in the NW part of the Peribaltic Syneclise. Carbonate and chalk lithofacies extend from the Olsztyn region to the east border of Poland. The non-deposition or island area located NE of Olsztyn no longer existed. Instead, there is a sedimentary gap related probably to an extensive current-dominated submarine shallows, extending in the Peribaltic Syneclise from the Lower Vistula region towards the NE (Jaskowiak-Schoeneichowa and Krassowska, 1988b; Dadlez et al., 1998). Stratigraphic gaps are also observed on salt-cored anticline crests of the Szczecin and Mogilno troughs (Jaskowiak, 1961; Jaskowiak-Schoeneichowa, 1972, 1981) and non- salt structures of the Pomeranian Trough (JaskowiakSchoeneichowa, 1976; Leszczyński, 2002b).

Interpretation of reflection seismic profiles along fault zones bounding the Mid-Polish Trough and along the present-day slope of the Mid-Polish Swell suggests that the late Turonian-Coniacian is the period when initial processes of tectonic inversion of the Mid-Polish Trough are first well-developed (Krzywiec, 2000, 2002a, b, 2006; Gutowski et al., 2003; Krzywiec et al., 2009). Inversion activity resulted in reduced subsidence in the axial zone and, therefore, in smaller thicknesses of the depositional succession in this area.

\section{CYCLE K4-II (SANTONIAN-EARLIEST CAMPANIAN) (FIG. 12)}

Cycle K4-II is dominated by carbonate-siliceous lithofacies being prevalent in the Mogilno and Uniejów troughs; however, marly lithofacies are locally significant in these areas. Carbon- 


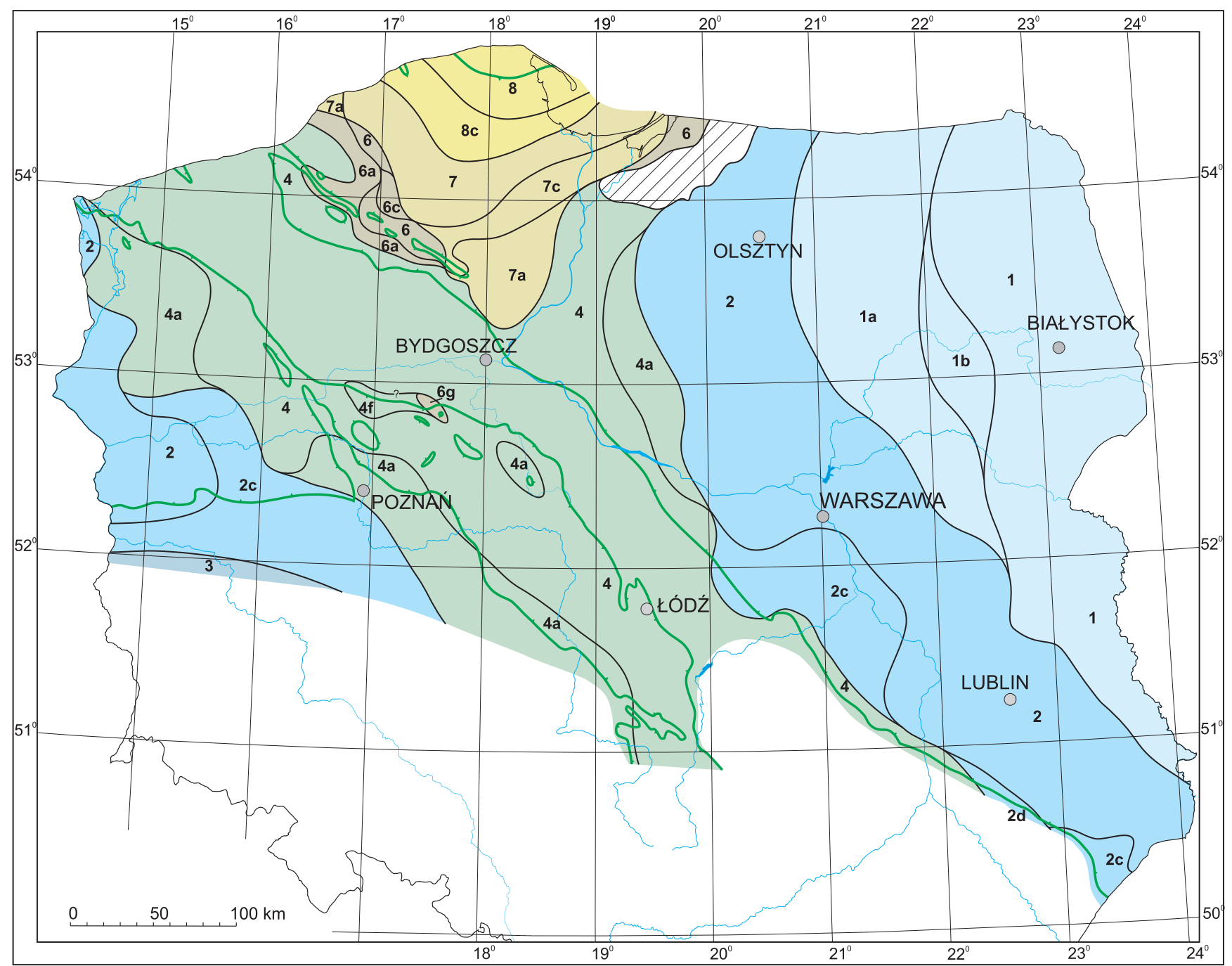

Fig. 11. Cycle K4-I (late Turonian-Coniacian) lithofacies

For explanations see Figure 9

ate-siliciclastic and siliciclastic lithofacies, represented by marly mudstones, siltstones and sandy marls, are found in the Szczecin, Mogilno and Uniejów troughs along the present-day Mid-Polish Swell slope, especially in the Pomeranian sector. Sandstone series, interpreted as gravity flow deposits forming submarine fan-type bodies (Fig. 16) within open-marine carbonate-siliceous deposits typical of a deeper marine environment, are known from near the rising Damasławek, Mogilno and Kłodawa salt structures (Jaskowiak-Schoeneichowa, 1977; Leszczyński, 2000, 2002a). Similar submarine slides/fans are also observed on seismic profiles within the Campanian-Maastrichtian succession in the Nowe Miasto-Zawichost Fault Zone (Krzywiec et al., 2009).

In the Gorzów Block, carbonate-siliceous lithofacies is gradually replaced towards the SW by marly and carbonate lithofacies accompanied occasionally by chalk-like limestones (Ośno region - Jaskowiak-Schoeneichowa, 1979, 1981).

Siliciclastic lithofacies in the Szczecin Trough (along the SW slope of the present-day Mid-Polish Swell) are separated from the siliciclastic area of the Łeba Elevation by a belt of carbonate-siliciclastic lithofacies in the Pomeranian Trough. A similar situation is observed in the Campanian and suggests different sources of clastic material to these areas.

Carbonate-siliceous lithofacies extend northeastwards to occupy most of the Płock Trough and extend along the SW margin of the Lublin Trough. Towards the NE, in the Płock and Lublin troughs, carbonate-siliceous and carbonate lithofacies are replaced by carbonate and marly lithofacies. Eastern and northeastern Poland is occupied by chalk lithofacies (Krassowska, 1976, 1986). A large non-depositional area is present east of Olsztyn (Jaskowiak-Schoeneichowa and Krassowska, 1988b; Dadlez et al., 1998). The non-depositional area that earlier existed south of the Vistula Lagoon, is no longer present.

Sedimentary or erosional gaps are recorded from salt-cored anticlines of the Szczecin and Mogilno troughs (Jaskowiak, 1961; Jaskowiak-Schoeneichowa, 1977, 1981; Leszczyński, $2002 b$ ), and from the Koszalin-Chojnice Zone (JaskowiakSchoeneichowa, 1976; Leszczyński, 2002b). 


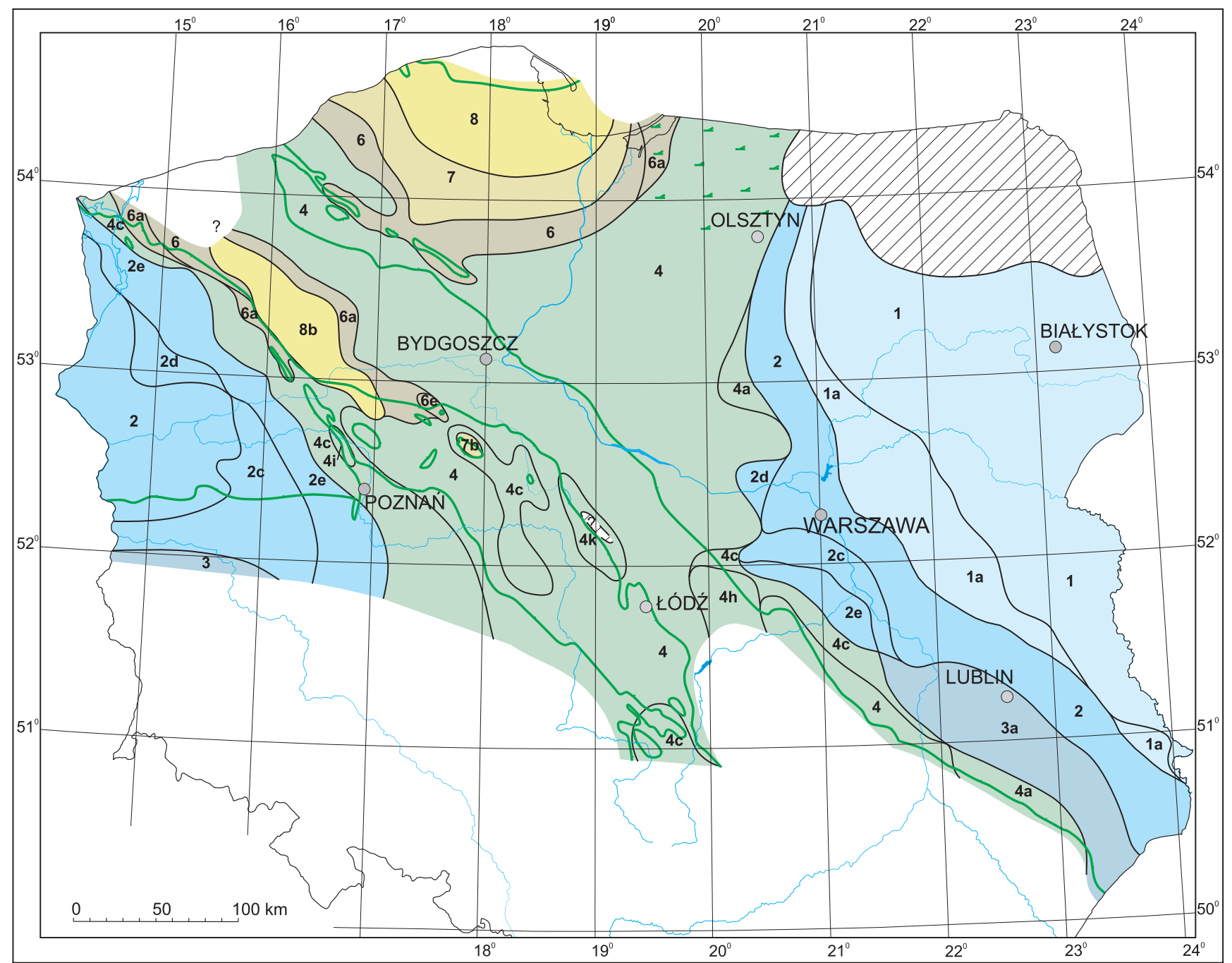

Fig. 12. Cycle K4-II (Santonian-earliest Campanian) lithofacies

For explanations see Figure 9

CYCLE K4-III

(LATE EARLY CAMPANIAN-EARLIEST MAASTRICHTIAN) (FIG. 13)

The general lithofacies distribution pattern is roughly similar to that of the previous cycle (Fig. 9). The characteristic feature is a higher proportion of carbonates at the expense of carbonate-siliceous rocks, and a smaller extent of siliciclastic facies in northern Pomeranian Trough and western Peribaltic Syneclise, where carbonate-siliceous and locally marl (Bytów IG 1) lithofacies predominate, and in the Leba Elevation. Chalk lithofacies, accompanied by limestones, occur in the Gorzów Block and in the SW part of the Szczecin Trough. From SW to NE, the lithofacies zonation is from chalk through carbonate (locally marly), to carbonate-siliceous lithofacies and muddy-sandy-marly lithofacies close to the present-day Mid-Polish Swell. This is considered to be a wide belt of carbonate-siliceous lithofacies that stretched along the Mid-Polish Trough from the Baltic coast to the SW flank of the Lublin Trough. This lithofacies is also prevalent in the Mogilno (accompanied by marly lithofacies) and Uniejów (along with carbonates) troughs. Marly and carbonate-siliceous lithofacies predominate in the transitional area between the Uniejów and Nida troughs (Hakenberg and Świdrowska, 1998). Carbonate lithofacies also extends from Olsztyn through Mazowsze to the Lublin and Roztocze regions. An extensive chalk area occupies Eastern Poland. Carbonate-siliceous lithofacies of the Pomeranian Trough (Jaskowiak-Schoeneichowa, 1976) grade northeastwards to sandstone lithofacies of the Łeba Elevation and Peribaltic Syneclise.

The very important lithological components of succession K4-III are gaizes and calcareous and sandy gaizes present, in particular, in Northern Poland. Sandstone series occur locally in some zones within the Mid-Polish Trough along the SW slope of the present-day Mid-Polish Swell, in the Mogilno Trough and near the Kłodawa salt diapir (JaskowiakSchoeneichowa, 1977, 1981; Leszczyński, 2000, 2002a).

The area of maximum subsidence extended in the present-day Szczecin, Mogilno and Uniejów troughs (over $800 \mathrm{~m}$ 


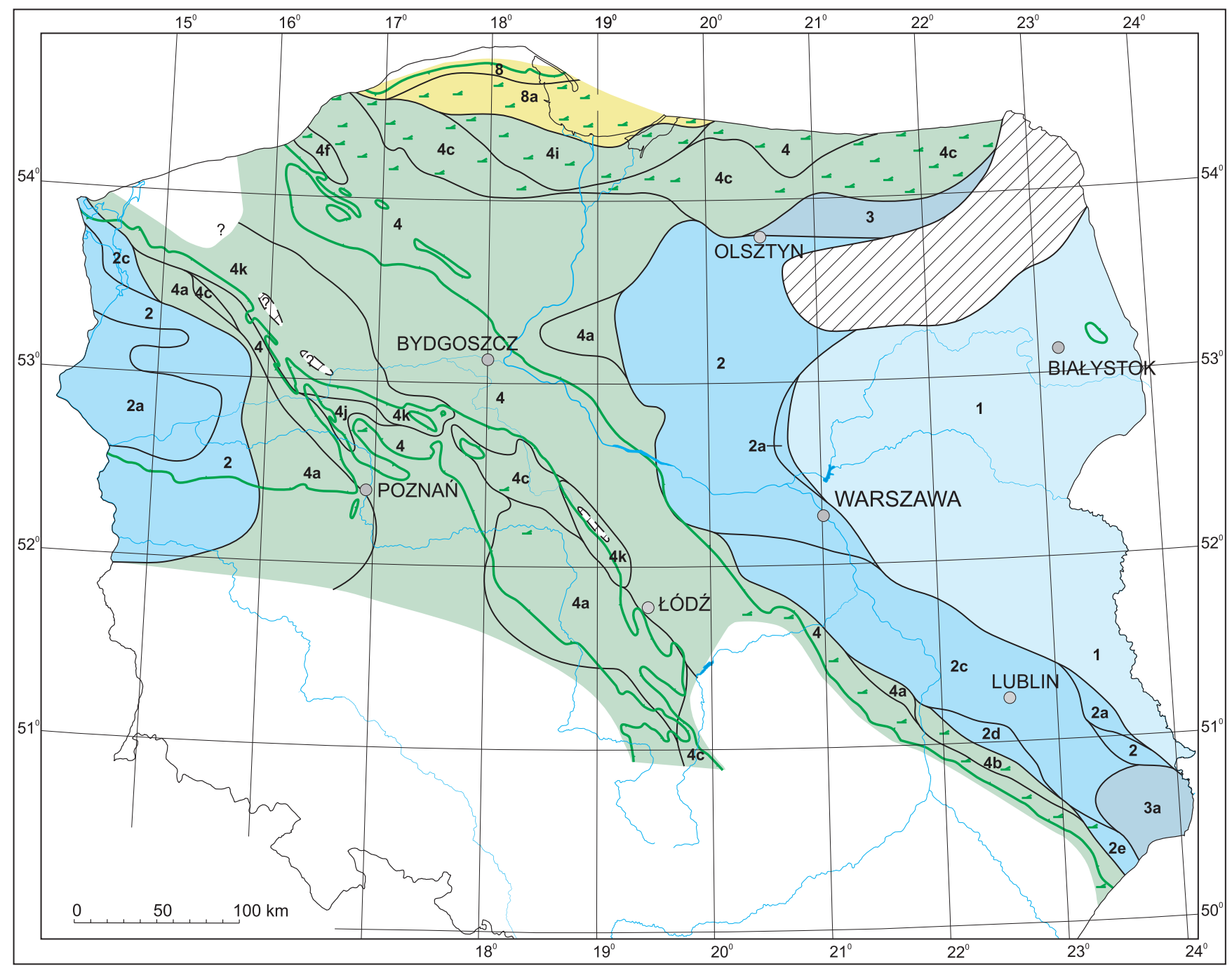

Fig. 13. Cycle K4-III (late early Campanian-earliest Maastrichtian) lithofacies

For explanations see Figure 9

of cycle K-III). The non-depositional area of NE Poland, already observed in the previous periods, shrank slightly and moved towards the south (Jaskowiak-Schoeneichowa and Krassowska, 1988b; Dadlez et al., 1998). Local sedimentary gaps are observed in the Koszalin-Chojnice Zone (JaskowiakSchoeneichowa, 1976; Leszczyński, 2002b).

CYCLES K4-IV-K4-V

\section{(LATE EARLY MAASTRICHTIAN- LATE MAASTRICHTIAN)} (FIG. 14)

The K4-IV-K4-V deposits occupy a smaller area than the previous cycles due to post-Cretaceous erosion. This cycle primarily relates to the late Maastrichtian which has been preserved mainly in the synclines, and to the area located SW of the present-day Mid-Polish Swell. The Maastrichtian has greater variability in lithofacies, both in the vertical section and across the basin, due to oscillatory sea level changes manifested by re- peated transgressive and regressive events (JaskowiakSchoeneichowa and Krassowska, 1988b). Carbonate-sandy and siliciclastic lithofacies occur in particular in the Pomeranian sector. Gaizes are very common, especially in northeastern Poland. Compared to the Campanian, chalk lithofacies in Western Poland occupy a slightly larger area. Towards the NE, chalk quickly grades laterally through carbonates into siliciclastics. From SW to NE, the distribution pattern includes chalk, carbonate, marly, carbonate-siliceous, carbonate-siliciclastic, carbonate-sandy and muddy-sandy-marly lithofacies.

Carbonate-siliceous (opoka) lithofacies occur predominantly in the Mogilno and Uniejów troughs. Sandstone and carbonate-sandy lithofacies play an important role in these areas close to the present-day Mid-Polish Swell.

In the Pomeranian Trough, calcareous sandstones, carbonates and sandy marls with gaize interbeds account for a significant proportion of the section. Carbonate-siliceous lithofacies (opoka) occurs in its northwestern and southeastern parts and 


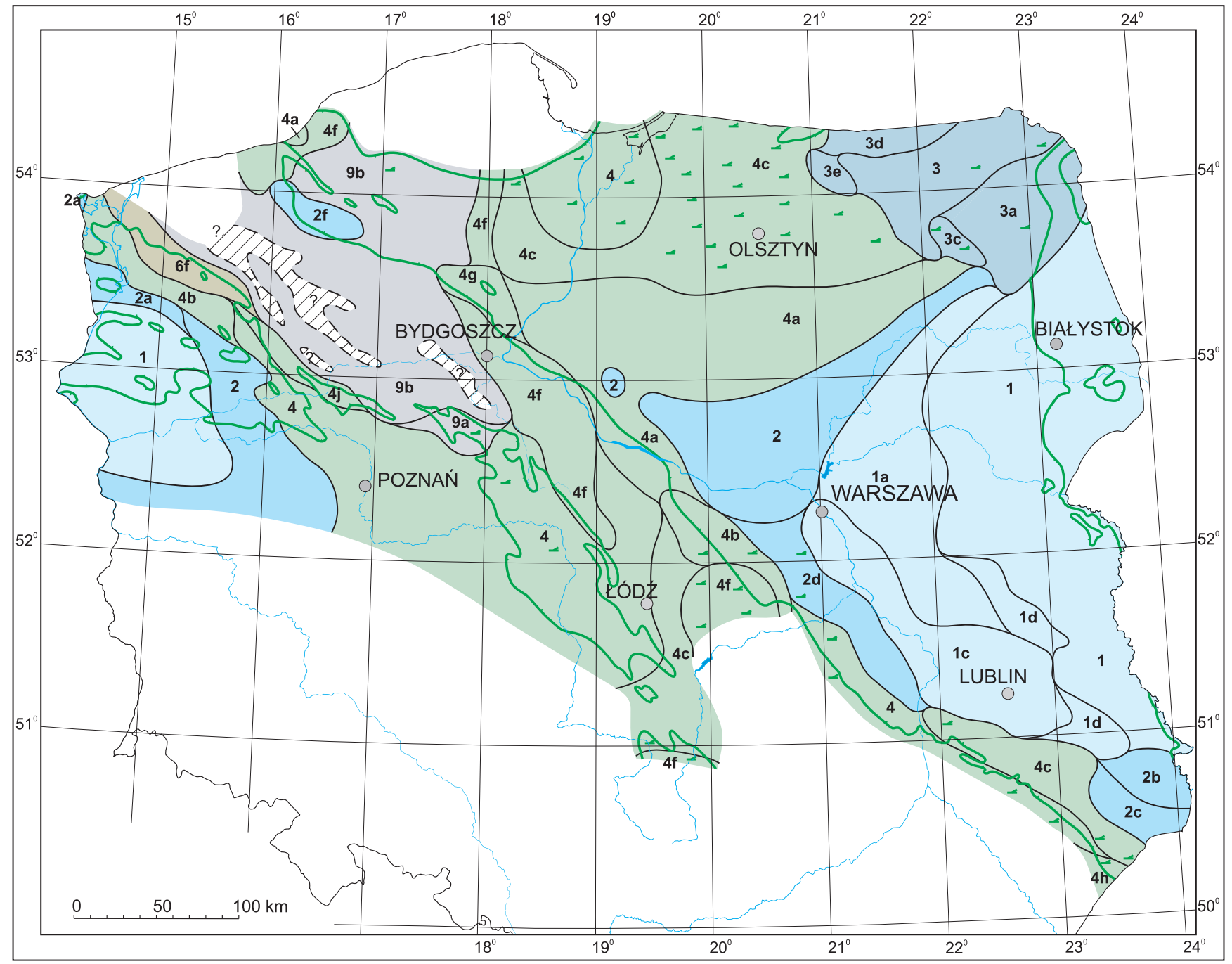

Fig. 14. Cycle K4-IV-K4-V (late early Maastrichtian-late Maastrichtian) lithofacies

For explanations see Figure 9

continues eastwards in the Płock Trough (accompanied by carbonate lithofacies) and in the south of the Peribaltic Syneclise where it co-occurs with marls. Carbonates are common south of Koszalin in the Pomeranian Trough. The lithofacies distribution pattern in Pomerania indicates more calm and unified sedimentary conditions towards the late Maastrichtian, with carbonate lithofacies becoming predominant (JaskowiakSchoeneichowa, 1987). Carbonate-siliceous and carbonate lithofacies, locally with gaize interbeds, compose the Maastrichtian succession in the western and central parts of the Płock Trough. In the south-east and east, the section is much more varied with additional marly and chalk components. To the $\mathrm{N}$ and NW of Warszawa, the upper Maastrichtian immediately overlies Campanian deposits and the boundary is often represented by a hardground (Jaskowiak-Schoeneichowa and Krassowska, 1983).

The non-depositional area that earlier existed in NE Poland is no longer present. Marly (with common sandy marls) and carbonate-siliceous (gaizes, local opokas) lithofacies predominate in this area. Muddy-marly and muddy-sandy-marly lithofacies are supplementary components in the north-central region. The lithofacies pattern of the Lublin region is also relatively variable. Carbonate-siliceous, and even sandy carbonate (with marls) lithofacies occur in the SW (areas 4h and 4c), close to slope of the present-day Mid-Polish Swell, passing towards the NE to carbonate (limestones accompanied by marls and chalk - areas 2c, 2b), and finally to chalk lithofacies (Krassowska, 1981; Świdrowska et al., 2008; Dubicka and Peryt, 2011).

In the extreme south-east, sandy to sandy-silty marls and gaizes, extending towards the Ukraine territory, are a significant component (Świdrowska, 2007; Świdrowska et al., 2008). A continuous succession from the Maastrichtian to Paleocene has recently been reported at Lechówka (east of Lublin) and described in detail by Racki et al. (2011). In most areas, there is a 


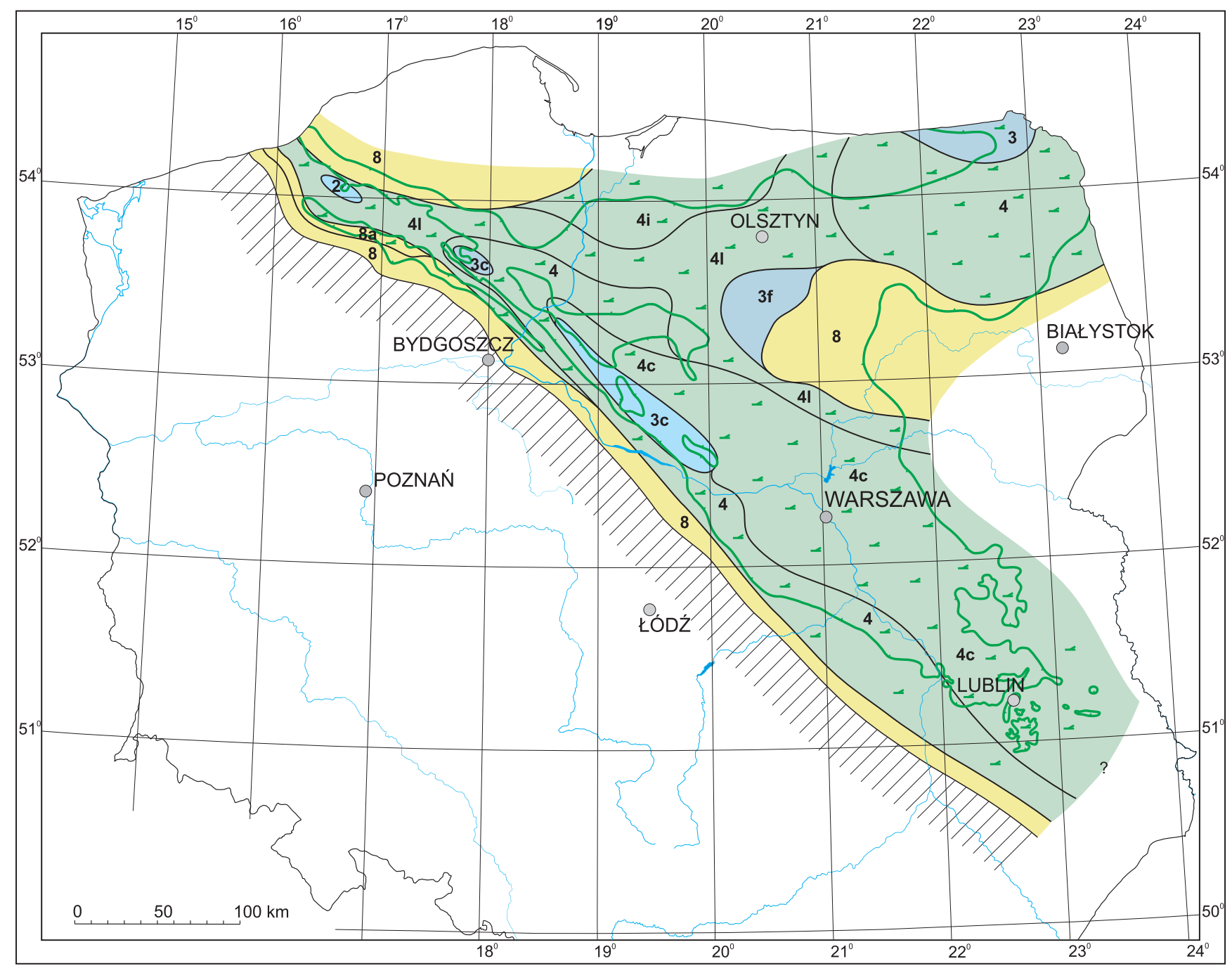

Fig. 15. Cycle Pc-I (Danian-?earliest Selandian) lithofacies

Extent of the Danian after Dadlez et al., 2000; for explanations see Figure 9

prominent sedimentary gap at the Maastrichtian/Danian boundary, locally represented by a hardground.

The zone of maximum subsidence moved to the Lublin Trough and southeastern part of the Płock Trough.

\section{CYCLE PC-I (DANIAN) (FIG. 15)}

The Early Paleocene (Danian) basin was the final stage of the evolution of the entire Late Cretaceous-Danian sedimentary megacycle. Słodkowska (2009) also reports the presence of lowermost Middle Paleocene (Selandian) deposits from the Mazury area. Danian deposits of the Polish Lowlands are known from the regions situated NE of the Mid-Polish Swell. In most areas, they are separated from the Upper Cretaceous by a distinct stratigraphic gap (Popiel, 1977; Krassowska, 1986; Jaskowiak-Schoeneichowa and Krassowska, 1988b). The Maastrichtian/Danian boundary is locally represented by a hardground (e.g., Popiel, 1977) or an erosional-omission sur- face (Machalski, 1998). In the Lublin region, the Maastrichtian deposits pass into Danian without any sedimentary breaks (Krassowska, 1986). The dominant Danian facies are gaizes, siliceous marls and marls locally with interbeds of marly limestone, representing the Puławy Formation (Pożaryska, 1965). Sandiness is commonly observed. Towards the basin margins, they grade into siliciclastic facies. The total thicknesses of the Danian are commonly a few tens of metres, locally exceeding 100 m (Jaskowiak-Schoeneichowa and Krassowska, 1988b; Krassowska, 1997).

\section{FINAL REMARKS}

The maps give an overall picture of the structural and lithofacies patterns of the Upper Cretaceous-Danian succession in the Polish Lowlands. Thickness analysis based on these two maps shows an increasing difference in subsidence rate during the Late Cretaceous between the areas extending on the two 


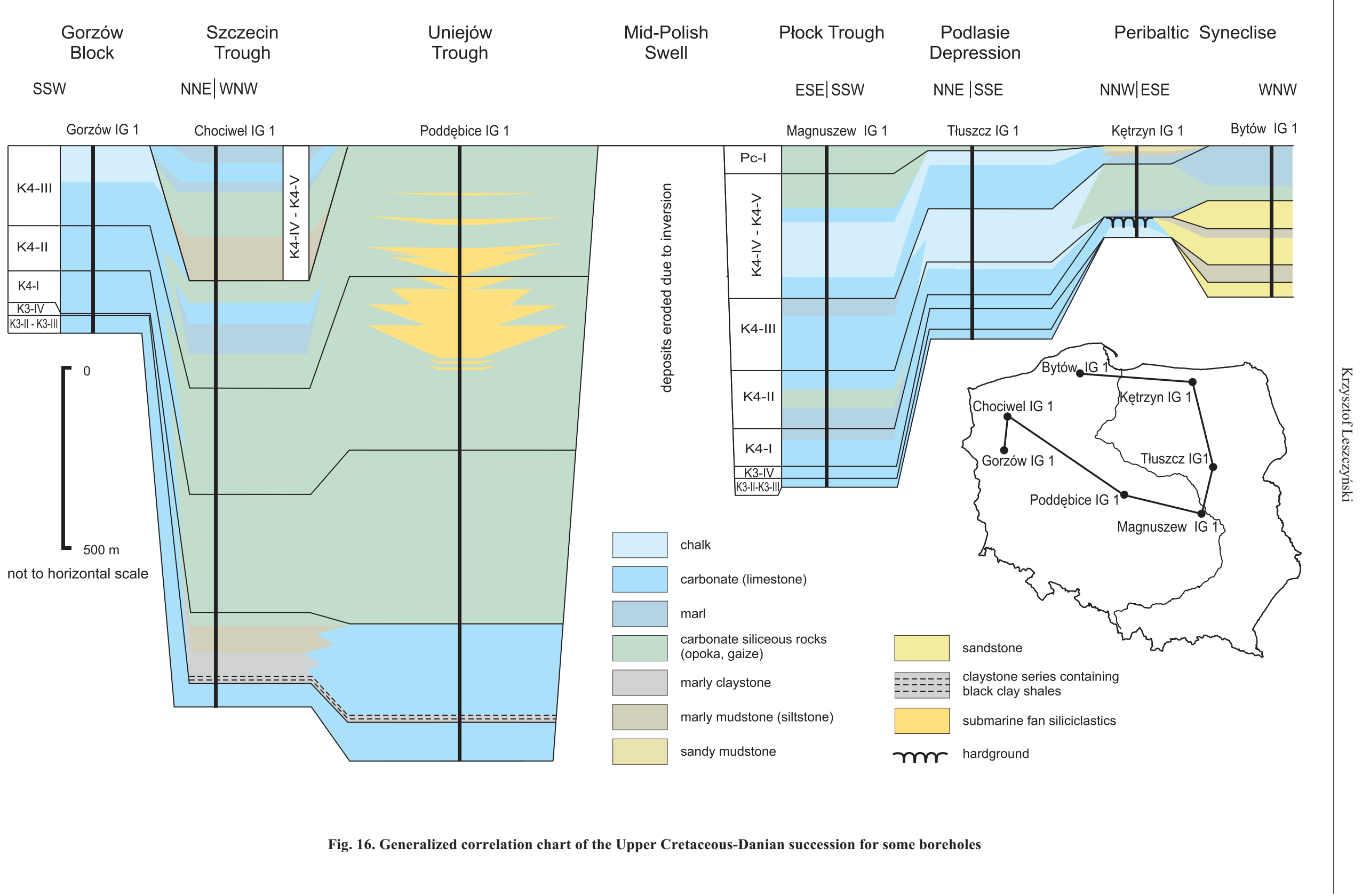


sides of the present-day Mid-Polish Swell, with a much higher subsidence during deposition of succession K4 in the area extending to the SW of it. In the area located to the NE of the Mid-Polish Swell, succession K4 is also thicker in the Kujavian and Lublin segments than in the Pomeranian segment. Succession K3 attains the greatest thickness in the Pomeranian and Kujavian segments, whereas in the Lublin region the values are lower. It shows that the maximum subsidence zone migrated in the Late Cretaceous from the Pomeranian and Kujavian segments towards the Kujavian and Lublin segments.

The ratio of the maximum thicknesses of successions K3 and $\mathrm{K} 4$ in the area situated to the SW of the present-day Mid-Polish Swell to the maximum thicknesses of these successions in the area located to the NE of it (calculated separately for the Pomeranian and Kujavian segments), indicates a greater difference in subsidence rate between the areas extending on either side of the present-day Mid-Polish Swell during deposition of succession K4 than during deposition of succession K3. A significantly greater subsidence occurred in the SW area during deposition of succession $\mathrm{K} 4$.

The lithofacies development was strongly controlled by eustatic and tectonic (predominantly inversion-related combined with halotectonic activity) processes. These affected the amount of accommodation space, carbonate productivity, supply of clastic material from extensive land areas and rising salt structures, and controlled the location and timing of sedimentary gaps and hardgrounds in some areas.

It is interpreted that the regional Late Cretaceous-Paleocene inversion tectonics in the European basins resulted from intraplate compressional/transpressional deformation (Mazur et al., 2005; Krzywiec et al., 2009), leading to the inversion of the Polish Basin, and resulting in significant uplift and erosion of its axial part (i.e. the Mid-Polish Trough), which was transformed into the Mid-Polish Swell. The trend of the inverted zone was controlled by the NW-SE-trending TeisseyreTornquist Zone (Znosko, 1998).

The overall lithofacies pattern of the Upper CretaceousDanian succession shows a general trend of continuous carbonate/chalk sedimentation in the west (Gorzów Block) and in the east, the zone of the Mid-Polish Trough with carbonate deposition replaced by carbonate-siliciclastic lithofacies with local sand-dominated series associated with submarine slides from the rising salt structures and uplifting Mid-Polish Swell, and, finally, the area of siliciclastic-dominated lithofacies extending in the north, as a result of the proximity to the clastic-supplying land of the Baltic Shield.

The greatest range of lithofacies is observed in the Pomeranian region, where the lithofacies pattern is constrained by inversion processes on the one hand and the supply of Scandinavian clastic material from the other.

Acknowledgements. I am greatly indebted to Dr M. Jaskowiak-Schoeneichowa and Dr A. Krassowska for donating a huge archive of manuscripts concerning the Upper Cretaceous from numerous boreholes, used in this study. I would also like to address special thanks to the reviewers: Prof. D. Peryt and Prof. O-V. Vejbaek for suggestions and corrections in the text, and especially to Prof. R. Mortimore for his valuable remarks and comments and for improving the English of the manuscript.

\section{REFERENCES}

ABDEL-GAWAD G. I. (1986) - Maastrichtian non-cephalopod mollusks (Scaphopoda, Gastropoda and Bivalvia) of the Middle Vistula Valley, Central Poland. Acta Geol. Pol., 36 (1-3): 69-224.

ARTHUR M. A., SCHLANGER S. O. and JENKYNS H. C. (1987) - The Cenomanian/Turonian Oceanic Anoxic Event, II. Palaeoceanographic controls on organic-matter production and preservation. Geol. Soc. Spec. Publ., 26: 401-420.

BIRKELUND T., HANCOCK J. M., HART M. B., RAWSON P. F., REMANE J., ROBASZYŃSKI F., SCHMID F. and SURLYK F. (1984) - Cretaceous stage boundaries - proposals. Bull. Geol. Soc. Denmark, 33: 3-20.

BRUMSACK H.-J. (1986) -Trace metal accumulation in black shales from the Cenomanian-Turonian boundary event. Lect. Notes in Earth Sc., 8: 337-343.

CIEŚLIŃSKI S. (1959) - The Albian and Cenomanian in the northern periphery of the Święty Krzyż Mountains (in Polish with English summary). Pr. Inst. Geol., 28

CIEŚLIŃSKI S. (1976) - Development of the Danish-Polish Furrow in the Holy Cross region in the Albian, Cenomanian and Lower Turonian (in Polish with English summary). Biul. Inst. Geol., 295: 249-271.

CIEŚLIŃSKI S. and JASKOWIAK M. (1973) - Kreda górna. Niecka mogileńsko-łódzka. In: Budowa geologiczna Polski. Stratygrafia. Mezozoik, 1 (2): 580-586. Warszawa.

DADLEZ R., ed. (1976) - Permian and Mesozoic of the Pomeranian Trough (in Polish with English summary). Pr. Inst. Geol., 79: 105-112.
DADLEZ R. (1980) - Tectonics of the Pomeranian Swell NW Poland (in Polish with English summary). Kwart. Geol., 24 (4): 741-747.

DADLEZ R., ed. (1998) - Mapa tektoniczna kompleksu cechsztyńsko-mezozoicznego na Niżu Polskim, 1:500 000. Państw. Inst. Geol., Warszawa.

DADLEZ R. (2001) - Mid-Polish Trough - geological cross-sections. Państw. Inst. Geol., Warszawa.

DADLEZ R. and MAREK S. (1974) - General outline of the tectonics of the Zechstein-Mesozoic complex in central and northwestern Poland (in Polish with English summary). Biul. Inst. Geol., 274: 111-148.

DADLEZ R. and MAREK S. (1997) - Development of the Permian and Mesozoic basins (in Polish with English summary). Pr. Inst. Geol., 153: 403-409.

DADLEZ R., DAYCZAK-CALIKOWSKA K., DEMBOWSKA J., JASKOWIAK-SCHOENEICHOWA M., MAREK S., SZYPERKO-ŚLIWCZYŃSKA A. and WAGNER R. (1976) - Permian-Mesozoic cover in the western part of the Peri-Baltic Syneclise (in Polish with English summary). Biul. Inst. Geol., 270: 143-163.

DADLEZ R., NARKIEWICZ M., STEPHENSON R. A., VISSER M. T. and Van WEES J.-D. (1995) - Tectonic evolution of the Mid-Polish Trough: modelling implications and significance for central European geology. Tectonophysics, 252 (1-4): 179-195.

DADLEZ R., JÓŹWIAK W. and MŁYNARSKI S. (1997) - Subsidence and inversion in the western part of Polish Basin - data from seismic velocities. Geol. Quart., 41 (2): 197-208. 
DADLEZ R., MAREK S. and POKORSKI J., eds. (1998) - Palaeogeographical atlas of the epicontinental Permian and Mesozoic in Poland Państw. Inst. Geol., Warszawa.

DADLEZ R., MAREK S. and POKORSKI J., eds. (2000) - Geological Map of Poland without Cainozoic deposits. Państw. Inst. Geol., Warszawa.

DADLEZ R., NARKIEWICZ M., POKORSKI J. and WAGNER R. (1998) - Subsidence history and tectonic controls on the Late Permian and Mesozoic development of the Mid-Polish Trough (in Polish with English summary). Pr. Państw. Inst. Geol., 65: 47-56.

DRAVIS J. J. (1979) - Rapid and widespread generation of recent oolitic hardgrounds on a high-energy Bahamian Platform, Eleuthera Bank, Bahamas. J. Sediment. Petrol., 49: 195-208.

DOORNENBAL J. C. and STEVENSON A. G., eds. (2010) - Petroleum geological atlas of the Southern Permian Basin Area. EAGE Publ. b.v. (Houten).

DUBICKA Z. and PERYT D. (2011) - Integrated biostratigraphy of Upper Maastrichtian chalk at Chełm (SE Poland). Ann. Soc. Geol. Pol., 81: 185-197.

ERLSTRÖM M. (1990) - Petrology and deposition of the Lund Sandstone, Upper Cretaceous, southwestern Scania. Sver. Geol. Unders. Forskningsrapp., 74.

GRIGELIS A. and LESZCZYŃSKI K. (1998) - Cretaceous. In: Structural Evolution of the Permian-Mesozoic Complex of Northeastern Poland, Lithuania and Adjacent Baltic Areas (eds. S. Marek and A. Grigelis). Państw. Inst. Geol., Warszawa.

GUTOWSKI J., KRZYWIEC P., WALASZCZYK I. and POŻARYSKI W. (2003) - Od ekstensji do inwersji — zapis aktywności północno-wschodniej brzeżnej strefy uskokowej świętokrzyskiego segmentu bruzdy środkowopolskiej w osadach jury górnej i kredy na podstawie interpretacji danych sejsmiki refleksyjnej. Tomy Jurajskie, 1: $124-125$

HAKENBERG M. (1978) - Albian-Cenomanian palaeotectonics and palaeogeography of the Miechów Depression northern part (in Polish with English summary). Stud. Geol. Pol., 58: 7-104.

HAKENBERG M. (1986) - Albian and Cenomanian in the Miechów Basin (Central Poland) (in Polish with English summary). Stud. Geol. Pol., 86: $57-85$.

HAKENBERG M. and ŚWIDROWSKA J. (1998) - Evolution of the Holy Cross segment of the Mid-Polish Trough during the Cretaceous. Geol. Quart., 42 (3): 239-262.

HANCOCK J. M. (1989) - Sea-level changes in the British region during the Late Cretaceous. Proc. Geol. Ass., 100 (4): 565-594.

HANCOCK J. M. and KAUFFMAN E. G. (1979) - The great transgressions of the Late Cretaceous. J. Geol. Soc. London, 136 (2): 175-186.

HANSEN H. J., RASMUSSEN K. L., GWOZDZ R., HANSEN J. M. and RADWAŃSKI A. (1989) - The Cretaceous/Tertiary boundary in Poland. Acta Geol. Pol., 39: 1-12.

HAQ B. U., HARDENBOL J. and VAIL P. R. (1988) - Mesozoic and Cenozoic chronostratigraphy and cycles of sea-level change. SEPM, Spec. Publ., 42: 71-108.

HARAPIŃSKA-DEPCIUCH M. (1972) - Petrography of the Upper Cretaceous deposits in the north-eastern part of the Polish Lowlands (in Polish with English summary). Biul. Inst. Geol., 261: 171-257.

HILBRECHT H. and DAHMER D. D. (1994) - Sediment dynamics during the Cenomanian-Turonian (Cretaceous) oceanic anoxic event in Northwestern Germany. Facies, 30: 63-84.

JASKOWIAK M. (1961) - Lithology and stratigraphy of the Upper Cretaceous in several boreholes on Lake Gopło in Kujawy (in Polish with English summary). Biul. Inst. Geol., 156: 61-77.

JASKOWIAK-SCHOENEICHOWA M. (1972) - The Upper Cretaceous in the Mogilno-Łódź Trough (in Polish with English summary). Kwart. Geol., 16 (2): 315-329.

JASKOWIAK-SCHOENEICHOWA M. (1976) - Kreda górna (łącznie z albem górnym i paleocenem dolnym). Pr. Inst. Geol., 79: 94-105.

JASKOWIAK-SCHOENEICHOWA M. (1977) - Kreda górna. Pr. Inst. Geol., 80: 99-112.

JASKOWIAK-SCHOENEICHOWA M. (1979) - Kreda górna (łącznie z albem górnym). Pr. Inst. Geol., 96: 77-90.
JASKOWIAK-SCHOENEICHOWA M. (1981) - Upper Cretaceous sedimentation and stratigraphy in north-western Poland (in Polish with English summary). Pr. Inst. Geol., 98.

JASKOWIAK-SCHOENEICHOWA M. (1987) - Kreda górna. Pr. Inst. Geol., 119: 140-151.

JASKOWIAK-SCHOENEICHOWA M. and KRASSOWSKA A. (1983) Kreda górna. Pr. Inst. Geol., 103: 177-197.

JASKOWIAK-SCHOENEICHOWA M. and KRASSOWSKA A. (1988a) - Mapy paleomiąższości i facji: alb górny-paleocen dolny. Centr. Archiw. Geol., Warszawa.

JASKOWIAK-SCHOENEICHOWA M. and KRASSOWSKA A. (1988b) - Palaeothickness, lithofacies and palaeotectonics of the epicontinental Upper Cretaceous in Poland (in Polish with English summary). Kwart. Geol., 32 (1): 177-198.

JASKOWIAK-SCHOENEICHOWA M. and POŻARYSKI W. (1979) Upper Cretaceous in Polish part of the Baltic Sea (in Polish with English summary). Kwart. Geol., 23 (2): 421-427.

JENKYNS H. C. (1980) - Cretaceous anoxic events: from continents to oceans. J. Geol. Soc. London, 137: 171-188.

JONES B. and DESROCHERS A. (1992) - Shallow platform carbonates. In: Facies Models - Response to Sea Level Change (eds. R. G Walker and N. P. James): 277-301. Geol. Ass. Canada.

JONES C. E. and JENKYNS H. C. (2001) - Seawater strontium isotopes, oceanic anoxic events, and seafloor hydrothermal activity in the Jurassic and Cretaceous. Am. J. Sc., 301: 112-149.

KERR A. C. (1998) - Oceanic plateau formation: a cause of mass extinction and black shale deposition around the Cenomanian-Turonian boundary? J. Geol. Soc., 155 (4): 619-626.

KOTAŃSKI Z. (1971a) - Zasady konstruowania ilościowych map geologicznych. In: Podstawowe zasady i metody geologicznej kartografii wgłębnej (eds. Z. Kotański and J. Sokołowski): 23-50. Wyd. Geol., Warszawa.

KOTAŃSKI Z. (1971b) - Mapy miaższościowe. In: Podstawowe zasady i metody geologicznej kartografii wgłębnej (eds. Z. Kotański and J. Sokołowski): 79-118. Wyd. Geol., Warszawa.

KOTAŃSKI Z. (1990) - Geologiczna kartografia wgłębna. Wyd. Geol., Warszawa.

KRASSOWSKA A. (1973) - Alb górny, kreda górna i paleocen. In: Magnuszew IG 1. Profile głębokich otworów wiertniczych. Państw. Inst. Geol., 4: 165-182.

KRASSOWSKA A. (1976) - The Cretaceous between Zamość, Tomaszów Lubelski and Kryłów (in Polish with English summary). Biul. Inst. Geol., 291: 51-101.

KRASSOWSKA A. (1981) - The characteristics of Cretaceous deposits in area of the Lublin Coal Basin (in Polish with English summary). Kwart. Geol., 25 (4): 703-716.

KRASSOWSKA A. (1986) - The Upper Cretaceous and Lower Paleocene in the vicinities of Lublin (in Polish with English summary). Kwart. Geol., 30 (3/4): 559-574.

KRASSOWSKA A. (1997) - Kreda górna. Sedymentacja, paleogeografia i paleotektonika. Pr. Inst. Geol., 153: 386-402.

KRZYWIEC P. (2000) - On mechanisms of the Mid-Polish Trough inversion - results of seismic data interpretation (in Polish with English summary). Biul. Państw. Inst. Geol., 393: 135-166.

KRZYWIEC P. (2002a) - Oświno structure (NW Mid-Polish Trough) salt diapir or inversion-related compressional structure? Geol. Quart., 46 (3): $337-346$.

KRZYWIEC P. (2002b) - Mid-Polish Trough inversion - seismic examples, main mechanisms and its relationship to the Alpine-Carpathian collision. European Geosciences Union Stephan Mueller Spec. Publ. Ser., 1: 151-165.

KRZYWIEC P. (2006) - Structural inversion of the Pomeranian and Kuiavian segments of the Mid-Polish Trough - lateral variations in timing and structural style. Geol. Quart., 51 (1): 151-168.

KRZYWIEC P., GUTOWSKI J., WALASZCZYK I., WRÓBEL G. and WYBRANIEC S. (2009) - Tectonostratigraphic model of the Late Cretaceous inversion along the Nowe Miasto-Zawichost Fault Zone, SE Mid-Polish Trough. Geol. Quart., 53 (1): 27-48. 
KUMP L. R., PAVLOV A. and ARTHUR M. A. (2005) - Massive release of hydrogen sulfide to the surface ocean and atmosphere during intervals of oceanic anoxia. Geology, 33: 397-400

KUTEK J. and GŁAZEK J. (1972) - The Holy Cross area, central Poland, in the Alpine cycle (in Polish with English summary). Acta Geol. Pol., 22 (4): 603-653.

LESZCZYŃSKI K. (1997) - The Upper Cretaceous carbonate-dominated sequences of the Polish Lowlands. Geol. Quart., 41 (4): 521-532.

LESZCZYŃSKI K. (2000) - The Late Cretaceous sedimentation and subsidence south-west of the Kłodawa Salt Diapir, central Poland. Geol. Quart., 44 (2): 167-174.

LESZCZYŃSKI K. (2002a) - The Cretaceous evolution of the Ponętów-Wartkowice Zone (in Polish with English summary). Pr. Państw. Inst. Geol., 176.

LESZCZYŃSKI K. (2002b) - The Late Cretaceous inversion and salt tectonics in the Koszalin-Chojnice and Drawno-Człopa-Szamotuły zones, Pomeranian sector of the Mid-Polish Trough. Geol. Quart., 46 (3): 347-362.

LESZCZYŃSKI K. (2010) - Lithofacies evolution of the Late Cretaceous basin in the Polish Lowlands (in Polish with English summary). Biul. Państw. Inst. Geol., 443: 33-54.

LESZCZYŃSKI K. and DADLEZ R. (1999) - Subsidence and the problem of incipient inversion in the Mid-Polish Trough based on thickness maps and Cretaceous lithofacies analysis - discussion (in Polish with English summary). Prz. Geol., 47 (7): 625-628.

LIBORIUSEN J., ASHTON A. and TYGESEN T. (1987) - The tectonic evolution of the Fennoscandian Border Zone in Denmark. Tectonophysics, 137: 21-29.

MACHALSKI M. (1998) - The Cretaceous-Tertiary boundary in Central Poland (in Polish with English summary). Prz. Geol., 46 (11): 1153-1161.

MACHALSKI M. and WALASZCZYK I. (1987) - Faunal condensation and mixing in the uppermost Maastrichtian/Danian Greensand (Middle Vistula, Central Poland). Acta Geol. Pol., 37 (1-2): 75-92.

MARCINOWSKI R. (1974) - The transgressive Cretaceous (Upper Albian through Turonian) deposits of the Polish Jura Chain. Acta Geol. Pol., 24 (1): 117-217.

MARCINOWSKI R., WALASZCZYK I. and OLSZEWSKA-NEJBERT D. (1996) - Stratigraphy and regional development of the mid-Cretaceous (Upper Albian through Coniacian) of the Mangyshlak Mountains, Western Kazakhstan. Acta Geol. Pol., 46 (1-2): 1-60.

MAREK S., ed. (1977) - Geological structure of the eastern part of the Mogilno-Łódź Trough (Gopło-Ponętów-Pabianice Zone) (in Polish with English summary). Pr. Inst. Geol., 80.

MAREK S., ed. (1983) - The geological structure of the Warsaw (Płock) Trough and its basement (in Polish with English summary). Pr. Inst. Geol., 103.

MAZUR S., SCHECK-WENDEROTH M. and KRZYWIEC P. (2005) Different modes of inversion in the German and Polish basins. Internat. J. Earth Sc., 94 (5-6): 782-798.

MORTIMORE R. N., WOOD C. J. and GALLOIS R. W. (2001) - British Upper Cretaceous. Stratigraphy. Geol. Conserv. Rev. Ser., 23.

MROZEK K. (1975) - Budowa geologiczna struktur wgłębnych w południowej części synklinorium łódzkiego. Wyd. Geol., Warszawa.

OLSZEWSKA-NEJBERT D. (2004) - Development of the Turonian/Coniacian hardground boundary in the Cracow Swell area (Wielkanoc quarry, Southern Poland). Geol. Quart., 48 (2): 159-170.

PERYT D. (1983) - Mid-Cretaceous microbiostratigraphy and foraminifers of the NE Mesozoic margin of the Holy Cross Mts., Central Poland. Acta Palaeont. Pol., 28: 417-466.

PERYT D. (1988) - Paleoecology of middle and late Cretaceous foraminifers from the Lublin Upland (SE Poland). Rév. Paléobiol., vol. spec., 2: 311-321.

PERYT D., WYRWICKA K., ORTH C., ATTREP M. and QUINTANA L. (1994) - Foraminiferal changes and geochemical profiles across the Cenomanian/Turonian boundary in central and southeast Poland. Terra Nova, 6: 158-165.

POPIEL J. S. (1977) - Lithology and stratigraphy of the uppermost Maastrichtian deposits from the Lublin and Chełm areas (in Polish with English summary). Kwart. Geol., 21 (3): 515-526.
POŻARYSKA K. (1965) - Foraminifera and biostratigraphy of the Danian and Montian in Poland. Palaeont. Pol., 14.

RACKI G., MACHALSKI M., KOEBERL C. and HARASIMIUK M. (2011) - The weathering modified iridium record of a new Cretaceous-Palaeogene site at Lechówka near Chełm, SE Poland, and its palaeobiologic implications. Acta Palaeont. Pol., 56 (1): 205-215.

RACZYŃSKA A., ed. (1987) - Geological structure of the Pomeranian Swell and its basement (in Polish with English summary). Pr. Państw. Inst. Geol., 119.

RAIS P., LOUIS-SCHMID B., BERNASCONI S. M. and WEISSERT H. (2007) - Paleoceanographic and paleoclimatic reorganization around the Middle-Late Jurassic transition. Palaeogeogr. Palaeoclimatol. Palaeoecol., 251: 527-546.

RAWSON P. F., DHONDT A. V., HANCOCK J. M. and KENNEDY W. J., eds. (1995) - Proceedings "Second International Cretaceous Symposium on Stage Boundaries”, Brussels 8-16 September, 1995. Bull. Inst. Royal Sc. Natur. de Belgique, Sc. de la Terre, 66.

RESAK M., NARKIEWICZ M. and LITTKE R. (2008) - New basin modelling results from the Polish part of the Central European Basin system: implications for the Late Cretaceous-Early Paleogene structural inversion. Internat. J. Earth Sc., 97: 955-972.

RESEARCH ON CRETACEOUS CYCLES (R.O.C.C.) GROUP (1986) Rhythmic bedding in Upper Cretaceous pelagic carbonate sequences. Varying sedimentary response to climatic forces. Geology, 14: $153-156$.

SAHAGIAN D., PINOUS O., OLFERIEV A. and ZAKHAROV V. (1996) - Eustatic curve for the Middle Jurassic-Cretaceous based on Russian Platform and Siberian stratigraphy - Zonal resolution. AAPG Bull., 80: $1433-1458$.

SCHLANGER S. O. and JENKYNS H. C. (1976) - Cretaceous oceanic anoxic events: causes and consequences. Geol. Mijnbouw, 55: 179-184.

SCHLANGER S. O., ARTHUR M. A., JENKYNS H. C. and SCHOLLE P. A. (1987) - The Cenomanian/Turonian oceanic anoxic event, I. Stratigraphy and distribution of organic carbon-rich beds and the marine $\delta^{13} \mathrm{C}$ excursion. Geol. Soc. Spec. Publ., 26: 371-399.

SŁODKOWSKA B. (2009) - Palynology of the Palaeogene and Neogene from the Warmia and Mazury areas (NE Poland). Geologos, 15 (3-4): 219-234.

STEPHENSON R. A., NARKIEWICZ M., DADLEZ R., van WEES J.-D. and ANDRIESSEN P. (2003) - Tectonic subsidence modelling of the Polish Basin in the light of new data on crustal structure and magnitude of inversion. Sediment. Geol., 156: 59-79.

SURLYK F. (1980) - Denmark, Finland, Sweden, Norway. In: Geology of the European Countries. Graham and Trotman. London: 1-50.

ŚWIDROWSKA J. (2007) - Cretaceousin Lublin area - sedimentation and tectonic conditions (in Polish with English summary). Biul. Państw. Inst. Geol., 422: 63-78.

ŚWIDROWSKA J. and HAKENBERG M. (1999) - Subsidence and the problem of incipient inversion in the Mid-Polish Trough based on thickness maps and Cretaceous lithofacies analysis discussion (in Polish with English summary). Prz. Geol., 47 (1): 61-68.

ŚWIDROWSKA J., HAKENBERG M., POLUHTOVIČ B., SEGHEDI A. and VIŠNÂKOV I. (2008) - Evolution of the Mesozoic basins on the southwestern edge of the East European Craton (Poland, Ukraine, Moldavia, Romania). Stud. Geol. Pol., 130: 3-130.

ŚWIERCZEWSKA-GŁADYSZ E. (2006) - Late Cretaceous siliceous sponges from the Middle Vistula River Valley (Central Poland) and their palaeoecological significance. Ann. Soc. Geol. Pol., 76: 227-296.

TUCKER M. E. and WRIGHT V. P. (1990) - Carbonate sedimentology. Blackwells, Oxford.

TURGEON S. C. and CREASER R. A. (2008) - Cretaceous oceanic anoxic event 2 triggered by a massive magmatic episode. Nature, 454 (7202): 323-326.

VEJBAEK O. V., ANDERSEN C., DUSAR M., HERNGREEN G. F. W., KRABBE H., LESZCZYŃSKI K., LOTT G. K., MUTTERLOSE J. and van der MOLEN A. S. (2010) - Cretaceous. In: Petroleum Geological Atlas of the Southern Permian Basin Area (eds. J. C. Doornenbal and A. G. Stevenson): 195-209. EAGE Publ. b.v. (Houten). 
VOIGT S., WAGREICH M., SURLYK F., WALASZCZYK I., ULIČNÝ D., ČECH S., VOIGT T., WIESE F., WILMSEN M., NIEBUHR B., REICH M., FUNK H., MICHALÍK J., JAGT J. W. M., FELDER P. J. and SCHULP A. S. (2008) - Cretaceous. In: Geology of Central Europe (ed. T. McCann). Geol. Soc., London, 2: 923-997.

WAGNER R., ed. (2008) - Tabela Stratygraficzna Polski. Polska Pozakarpacka. Państw. Inst. Geol., Warszawa.

WAGNER R., LESZCZYŃSKI K., POKORSKI J. and GUMULAK K. (2002) - Paleotectonic cross-sections through the Mid-Polish Trough. Geol. Quart., 46 (3): 293-306.

WALASZCZYK I. (1987) - Mid-Cretaceous events at the marginal part of the Central European Basin (Annopol-on-Vistula section, Central Poland). Acta Geol. Pol., 37 (1-2): 61-74.

WALASZCZYK I. (1992) - Turonian through Santonian deposits of the Central Polish Uplands; their facies development, inoceramid paleontology and stratigraphy. Acta. Geol. Pol., 42 (1-2): 1-122.
WILSON M. A. and PALMER T. J. (1992) - Hardgrounds and hardground faunas. University of Wales, Aberystwyth, Institute of Earth, Stud. Publ., 9: 1-131.

ZIEGLER P. A. (1982) - Geological atlas of western and central Europe. Elsevier. Amsterdam.

ZNOSKO J., ed. (1998) - Atlas tektoniczny Polski. Państw. Inst. Geol., Warszawa.

ŻARSKI M., JAKUBOWSKI G. and GAWOR-BIEDOWA E. (1998) - The first Polish find of a Lower Paleocene crocodile Thoracosaurus Leidy, 1852: geological and palaeontological description. Geol. Quart., 42 (2): $141-160$

ŻELICHOWSKI A. M. (1971) - Mapy geologiczno-strukturalne. In: Podstawowe zasady i metody geologicznej kartografii wgłębnej (eds. Z. Kotański and J. Sokołowski): 51-78. Wyd. Geol., Warszawa. 